\title{
Advanced Recovery Techniques for Waste Materials from IT and Telecommunication Equipment Printed Circuit Boards
}

\author{
Horațiu Vermeșan 1,*(D), Ancuța-Elena Tiuc ${ }^{1, *(\mathbb{D})}$ and Marius Purcar ${ }^{2}$ \\ 1 Faculty of Materials and Environmental Engineering, Technical University of Cluj-Napoca, \\ Bd. Muncii 103-105, Cluj-Napoca 400641, Romania \\ 2 Faculty of Electrical Engineering, Technical University of Cluj-Napoca, G Baritiu, nr. 26, \\ Cluj-Napoca 400027, Romania; Marius.Purcar@ethm.utcluj.ro \\ * Correspondence: Horatiu.Vermesan@imadd.utcluj.ro (H.V.); Ancuta.Tiuc@imadd.utcluj.ro (A.-E.T.)
}

Received: 24 October 2019; Accepted: 18 December 2019; Published: 20 December 2019

\begin{abstract}
Waste from information technology (IT) and telecommunication equipment (WITTE) constitutes a significant fraction of waste from electrical and electronic equipment (WEEE). The presence of rare metals and hazardous materials (e.g., heavy metals or flame retardants) makes the necessary recycling procedures difficult and expensive. Important efforts are being made for Waste Printed Circuit Board (WPCB) recycling because, even if they only amount to $5-10 \%$ of the WITTE weight, they constitute up to $80 \%$ of the recovered value. This paper summarizes the recycling techniques applicable to WPCBs. In the first part, dismantling and mechanical recycling techniques are presented. Within the frame of electro-mechanical separation technology, the chain process of shredding, washing, and sieving, followed by one or a combination of magnetic, eddy current, corona electrostatic, triboelectrostatic, or gravity separation techniques, is presented. The chemical and electrochemical processes are of utmost importance for the fine separation of metals coming from complex equipment such as WPCBs. Thermal recycling techniques such as pyrolysis and thermal treatment are presented as complementary solutions for achieving both an extra separation stage and thermal energy. As the recycling processes of WPCBs require adequate, efficient, and ecological recycling techniques, the aim of this survey is to identify and highlight the most important ones. Due to the high economic value of the resulting raw materials relative to the WPCBs' weight and composition, their recycling represents both a necessary environmental protection action, as well as an economic opportunity.
\end{abstract}

Keywords: recycling processes; IT waste; WEEE; Waste Printed Circuit Board

\section{Introduction}

Waste management is associated with the manufacturing process of all products. The most recommended waste management approaches include the reduction of the quantity of generated waste, the expansion of environmentally friendly recycling technologies, and the maximization of re-use while at the same time fulfilling governmental measures related to waste management.

In recent decades, the electrical and electronic equipment (EEE) business has become one of the fastest expanding manufacturing industries globally. Multiple factors, such as scientific and technological innovations, lifestyle changes, and life span reduction of EEE products, have resulted in the vast accumulation of waste from electrical and electronic equipment (WEEE) within the waste stream (5\% of total solid wastes [1]). The accelerated evolution of the EEE manufacturing industry has fundamentally transformed a multitude of significant fields in our society, such as entertainment, communication, transportation, and virtual payment. Therefore, one may forecast that the demand for EEE, from both industries and individuals, will continue to exhibit a high rate of increase, while 
the shortened life span of such products raises a global sustainability concern [2-4]. Studies have demonstrated a mathematical relationship among e-waste generated volumes and anthropogenic behavior in developed (and developing) countries [5]. According to the predictions made in the work of Baldé et al. [6], the total quantity of WEEE will exceed 50 million tons by 2021.

WEEEs contain many materials of high economic value, but they also represent possible environmental threats in the case of unregulated disposal processes [7]. At the same time, WEEE recycling constitutes one of the most important secondary raw materials sources. However, the economic potential of these industrial procedures has been rarely demonstrated rigorously in studies $[8,9]$.

The European WEEE Directive classifies WEEE into four categories (Category 1, Category 2, Category 3, and Category 4):

- Category 1 covers large household appliances (fridges, washing machines, air conditioners, etc.);

- Category 2 covers small household appliances (vacuum cleaners, toasters, fryers, etc.);

- Category 3 covers IT and telecommunication equipment (ITTE) (PCs, tablets, notebooks, smartphones, etc.);

- Category 4 covers consumer equipment (e.g., TVs, stereo systems, digital cameras, etc.).

Category 1 and 2 contain low-grade Printed Circuit Boards (PCBs) [10]. In contrast, Category 3 and 4 generally contain medium high-grade PCBs. Among these different categories, the quantity of waste from information technology and telecommunication equipment (WITTE) (Category 3) has been increasing very quickly due to rapid development in the field [11,12]. The life span of the newest computer generations keeps shortening when compared to older equipment. Betts et al. [13] report that today's computers have an average lifespan of only three years. Moreover, the ratio of obsolete computers is higher in developing countries as compared to developed countries [14]. Obsolescence [15] is a concept that considers to what extent customers may be influenced to replace their electronic equipment by sociocultural factors such as fads, marketing, or consumption incentives. Technological obsolescence is viewed as improving the circulation of goods. Nevertheless, the US alone creates 0.423 million tons of waste computers, among which only $40 \%$ are considered for further recycling, while the rest of the scrap computers are shipped to developing countries, dumped in landfills, or incinerated [16-18]. Accounting for these circumstances, the WITTE alone makes up one-third of the global WEEE generated yearly $[19,20]$.

WITTE represents ca. 15\% of WEEE [21]. Within the entire WEEE quantity, the Waste Printed Circuit Boards (WPCBs) percentage [22,23] is high (3\% to 6\%) [24-26]. Moreover, it is even higher in some EEEs, such as mobile phones (21.30\%), personal computer control units $(18.76 \%)$, and color television sets $(7.04 \%)$. Metals represent about $40 \%$ of the WPCB overall value, while non-metal elements constitute the rest [8] (see Figure 1).

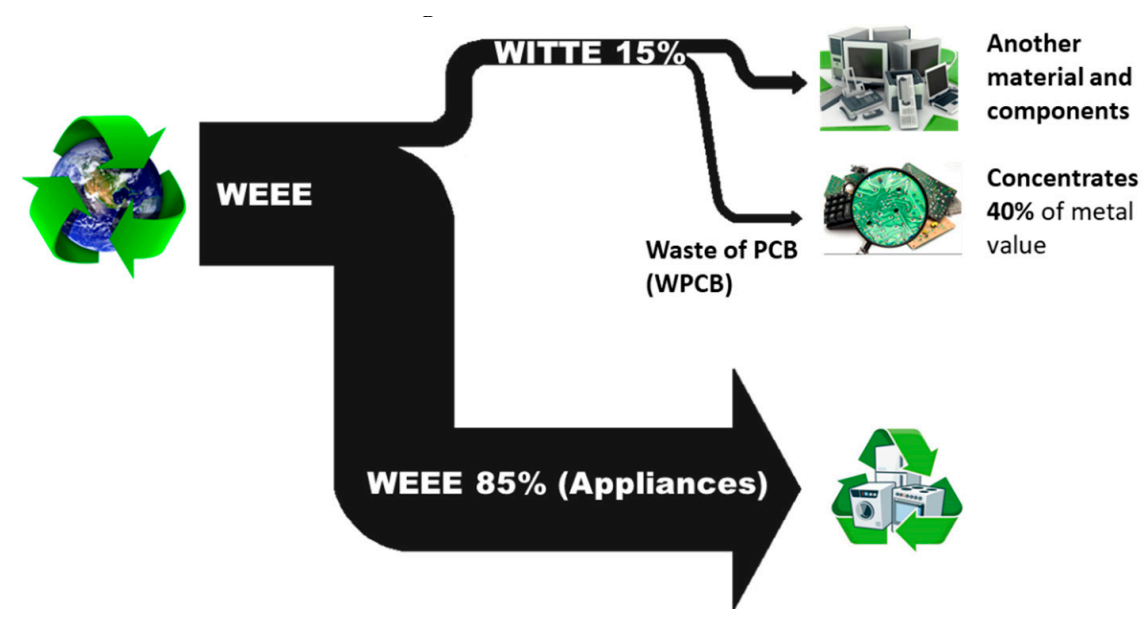

Figure 1. Distribution of waste from information technology and telecommunication equipment (WITTE) in waste from electrical and electronic equipment (WEEE). 
Therefore, PCBs are currently considered as an example of "secondary resources" in the electronic waste stream, and they are perceived as the most complex [27], valuable, and hazardous component of WEEE [28-30]. However, over time, the composition of the materials used in IT and telecommunication equipment is gradually changing [31,32]. Figure 2 represents the time variation (2006 and 2016) of the material composition in a desktop and the comparison between the material composition in desktops and laptops (reported in 2016). A decrease in the weight of precious metals and minerals, as well as a significant increase in laptop plastics, compared to desktops, can be noticed from the 2016 data. Various kinds of metals, such $\mathrm{Al}, \mathrm{Cu}$, and $\mathrm{Sn}$, and the precious metals gold (Au), silver (Ag), platinum (Pt), and palladium (Pd) [33-36] are used in PCBs for electrical conduction. PCBs have a complex composition consisting of a polymer (epoxy resin or fiberglass-based) component, various metals, and ceramic materials [37]. Plastic materials from PCBs contain fire-retardant substances for fireproofing the board. Thus, WPCBs should be properly disposed of and recycled: Firstly, because of their pollutant content (such as brominated flame retardants, polybrominated dibenzo-p-dioxin and dibenzofurans, chlorinated dioxin, and polycyclic aromatics) [38,39]; and secondly, in consideration of the sustainable management of resources and environmental protection (due to the large amounts of metals and nonmetals-mainly resin, derived from petroleum, a nonrenewable resource) [40-42].

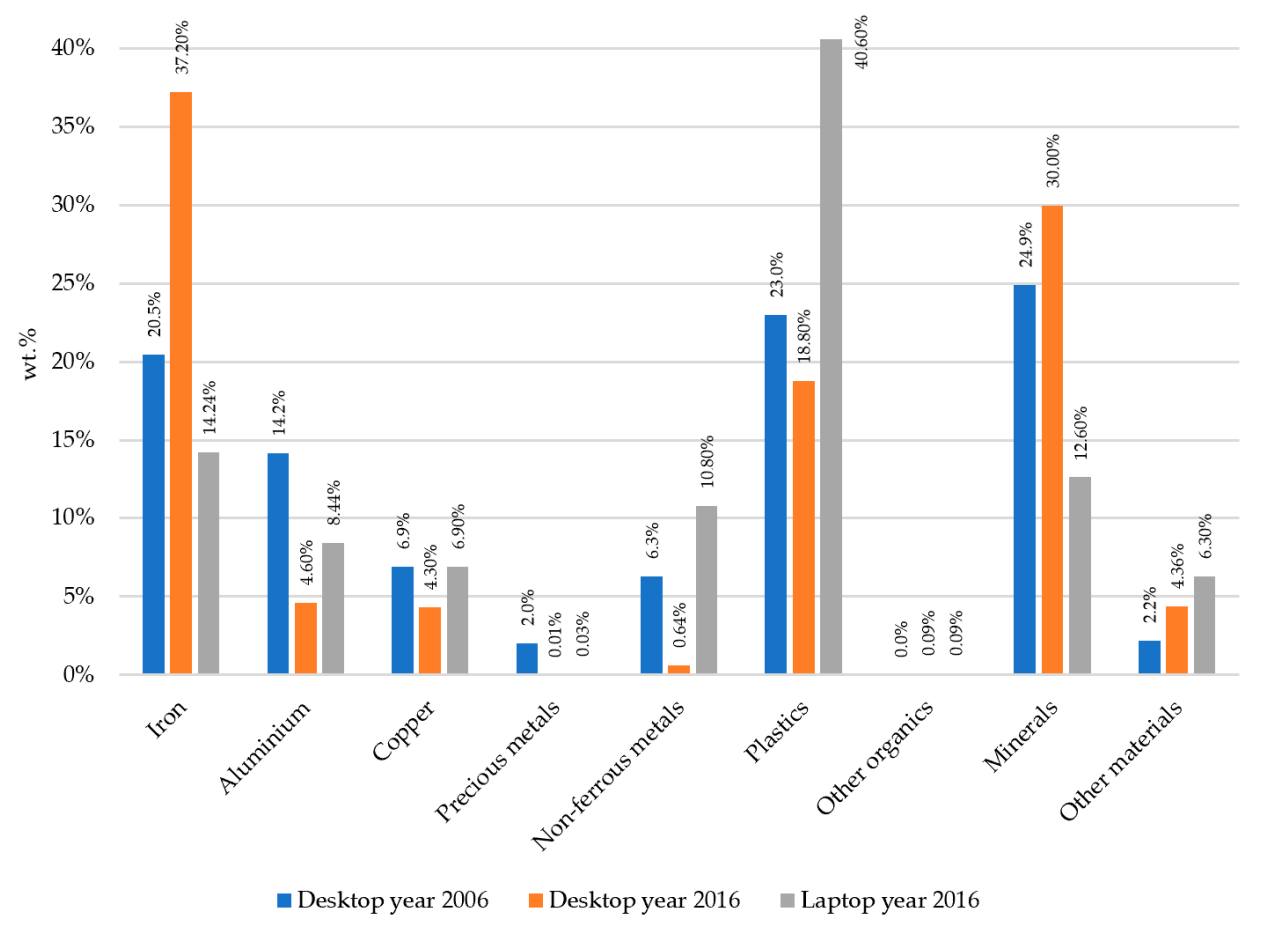

Figure 2. Material composition of computers from 2006 to 2016 [4].

Over the last few years, the European Union has issued various directives aimed at supporting the correct and effective treatment and disposal of WEEE in general, and WITTE in particular $[15,43]$.

The directive 2012/19/EC targeted the promotion of recycling, recovery, and reuse of WEEE in order to reduce its disposal in landfills [44]. Electronic waste collection and consequent material recovery processes in the European Union are loosely based on the "categories" defined by the WEEE directive. However, a more comprehensive product classification can be made, based on an alternative approach relying on the concept of a product family. A product family is denoted by products sharing some commonalities that are significant for their end-of-life management [45]. According to the EU WEEE directive mentioned above, PCBs with an area larger than a specified threshold $\left(10 \mathrm{~cm}^{2}\right)$ must be dealt with exclusively, and thus need to be removed from WEEE. The high prevalence of PCBs is a key component of all electronic and electrical equipment. PCBs may contain valuable metals such as $\mathrm{Au}, \mathrm{Pt}$, and $\mathrm{Pd}$, or other metals like iron $(\mathrm{Fe})$, copper $(\mathrm{Cu})$, zinc $(\mathrm{Zn})$, lead $(\mathrm{Pb})$, and $\mathrm{Ag}$ [46]. The PCB is 
composed of a combination of thermoplastic material and epoxy resin treated with flame retardants substances that are challenging to recycle [47]. Disassembled PCBs (except power boards) usually contain metal films, Au or Au-plated connectors, pins, slots, integrated circuits (IC), chips of different sizes, resistors, condensers, etc. There may be several types of condensers in the PCBs of desktop computers. Aluminum (Al) capacitors have a higher $\mathrm{Al}$ content and a low amount of $\mathrm{Cu}$ and do not contain precious metals (Table 1), [48].

Table 1. Metal content mg / Kg in Printed Circuit Boards (PCBs) from waste desktop computers [48].

\begin{tabular}{cccccccc}
\hline Electronic Parts of PCB & $\begin{array}{c}\text { Weight/Piece } \\
(\mathbf{g})\end{array}$ & $\begin{array}{c}\mathbf{A g} \\
(\mathbf{g} / \mathbf{K g})\end{array}$ & $\begin{array}{c}\mathbf{A u} \\
(\mathbf{g} / \mathbf{K g})\end{array}$ & $\begin{array}{c}\mathbf{P d} \\
(\mathbf{g} / \mathbf{K g})\end{array}$ & $\begin{array}{c}\mathbf{P t} \\
(\mathbf{g} / \mathbf{K g})\end{array}$ & $\begin{array}{c}\mathbf{C u} \\
(\mathbf{g} / \mathbf{K g})\end{array}$ & $\begin{array}{c}\mathbf{A l} \\
(\mathbf{g} / \mathbf{K g})\end{array}$ \\
\hline Aluminum capacitor & 5.551 & 0 & 0.001 & 0.0001 & 0.001 & 7.4 & 670 \\
$\quad$ Tantalum capacitor & 0.27 & 0 & 0.14 & 0 & 0 & 0.22 & 1.3 \\
$\quad$ Ceramic capacitor & 0.218 & 0.06 & 0.036 & 0 & 0 & 510 & 0.25 \\
$\quad$ Smallest capacitor & 0.006 & 100 & 0.008 & 35 & 5 & 2.4 & 1.3 \\
$\quad \begin{array}{c}\text { Electronic resistance } \\
\quad \text { Plastic IC chip }\end{array}$ & 1.625 & 57.602 & 3.601 & 2.509 & 0 & 380.4 & 34.94 \\
$\begin{array}{c}\text { Central processing units } \\
\text { (without metal film) }\end{array}$ & 9.913 & 12.2 & 15.398 & 0.083 & 0.264 & 901 & 4.879 \\
$\quad \begin{array}{c}\text { Integrated Graphics } \\
\text { Processor (IGP) }\end{array}$ & 4.02 & 0.055 & 0.517 & 0.075 & 0 & 500 & 0 \\
$\quad \begin{array}{l}\text { Integrated Drive } \\
\text { Electronics Connector }\end{array}$ & 0.681 & 0.016 & 0.37 & 0.007 & 0 & 770 & 8.8 \\
$\begin{array}{c}\text { Small Computer System } \\
\text { Interface Connector }\end{array}$ & 0.882 & 0.002 & 0.7 & 0 & 0.052 & 0.21 & 110 \\
\hline
\end{tabular}

In the older types of motherboards, the solders generally consist of an 60/40 Tin Lead alloy. Conversely, the solders of more recent motherboard types are Lead-free Tin wire consist in Sn99Cu0.7Ag0.3 [49]. Integrated circuit chips, central processing units (CPUs), Au pins, connectors, and small capacitors also contain minor amounts of precious metals, of high scrap value [48]. In order to improve the scrap quality and value, the metal or plastic frames, heat sinks, $\mathrm{Al}$ capacitors, and $\mathrm{Cu}$ inductors from the PCBs before transferring the PCBs to a further recovery process, precious metals are to be removed. The $\mathrm{Al}$ and $\mathrm{Cu}$ scrap are usually transferred to pyrometallurgical recovery sites. To recuperate large components of PCB (speakers, fan, batteries, heat sinks, and metal films), the boards should be verified and disassembled manually. After waste monitors and computers have been dismantled, six PCBs categories typically result (Figure 3).

The potential value of each scrap PCB varies mainly according to its size and number of Au-plated connectors, Au pins, small capacitors, integrated circuit chips, and the surface of Au plates. Recent technology means that all electronic components can be removed from the PCB through a pyrolysis method. Adequate peeling, separation, and sorting of integrated circuit chips, CPUs, connectors, and capacitors from PCBs are all intermediate steps of the PCB recycling process [48]. Once the electronic components are separated from the PCBs and sorted, each category should be further processed and refined. Specific hydrometallurgical recovery and refining technologies allow higher precious-metal recuperation rates [50]. Many PCBs (Peripheral Component Interconnect-PCI cards and memory modules) contain 18-carat pure Au [51]. The Au plating can be peeled off by a hydrometallurgical process, in acid environment [52]. Hence, $99.99 \% \mathrm{Au}$ is recovered with an efficiency of $99 \%$. At the same time, the blank motherboards could be shipped to an $\mathrm{Ag}$, $\mathrm{Cu}$, and tin recovery plant. 


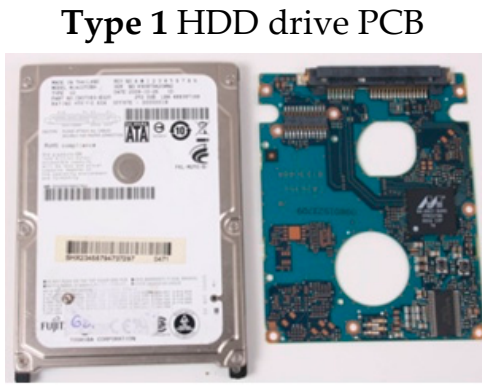

Type 4 LCD monitor PCB

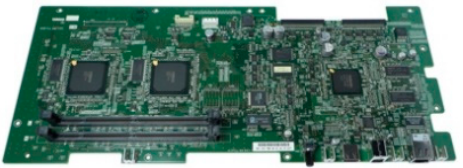

Type 2 Memory module PCB

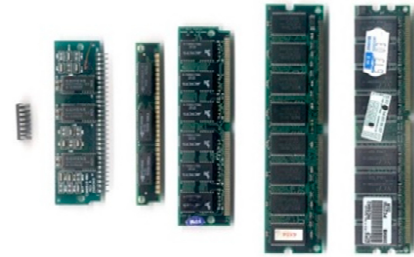

Type 5 The motherboard

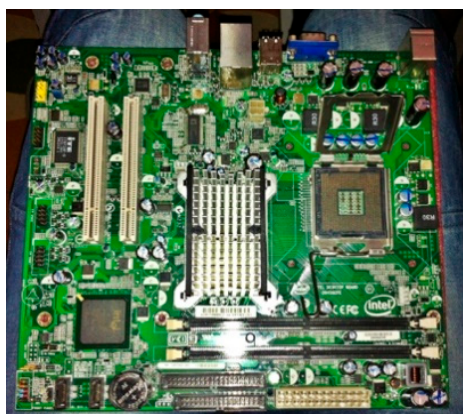

Type 3 PCI card

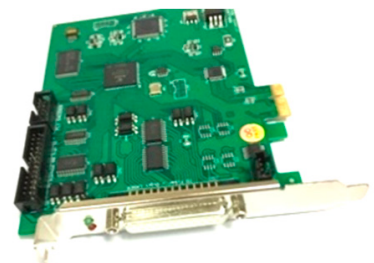

Type 6 Power board PCB

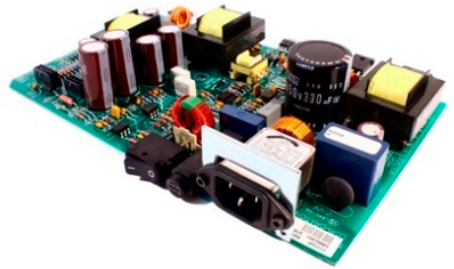

Figure 3. Types of PCBs after dismantling waste computers and monitors.

An emphasis on WPCB recycling techniques is presented in this article, as they have the highest economic value in terms of their volume (weight) and composition. Recovery from the WPCB of these metals may decrease, to some degree, the total global demand for new supplies. WPCB recycling also helps reduce waste disposal in landfills. Just $15 \%$ of the global WPCB is entirely recycled, even with all the possible benefits [53]. Therefore, knowledge of the main recycling techniques represents a very important initial step in increasing the recycling rate of these wastes.

\section{Recycling Techniques of WPCBs}

The PCB recycling process can be divided into three main phases-disassembly, treatment, and refinement-resulting in a set of (almost pure) raw materials [54].

1. Disassembly [55]: Dangerous products (e.g., Al radiators, capacitors, batteries, etc.), valuable products (e.g., microprocessors and memories), and metallic and plastic fixtures are completely removed from the main board, in order to avoid further contamination during the recycling processes;

2. Treatment: PCBs are disintegrated into micro parts, using several devices (e.g., shredders and grinders) to become a uniform powder. Subsequently, these powders are separated into metals and nonmetals by manipulating their different physical concepts (e.g., thickness, magnetism, or weight).

3. Refinement: Metal powders are processed using the technologies available (e.g., pyrometallurgy, hydrometallurgy, or a combination of them) to obtain almost pure secondary resources [56].

\subsection{Disassembly Process}

The removal of dangerous components and the recovery of recyclable materials requires a variety of tools. Disassembly is a systematic approach enabling the detachment of components (e.g., subassemblies) from a product (e.g., partial disassembly) or the separation of a product into all its parts (e.g., full disassembly) for a specific purpose $[57,58]$. Disassembly is an essential step for an efficient WEEE recycling process (Figure 4) [59]. 


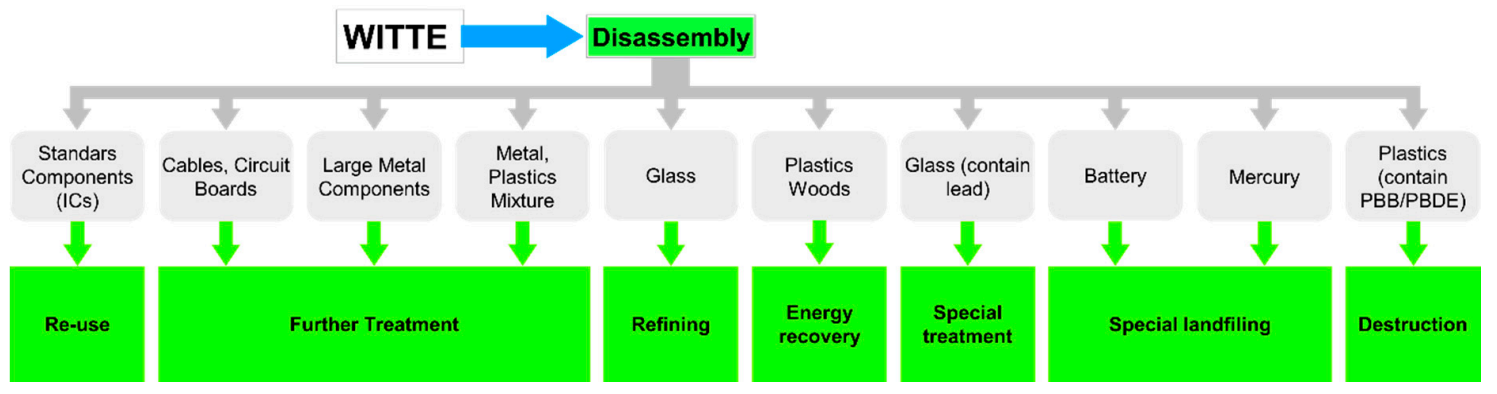

Figure 4. Recycling process for WITTE [59].

The aim of disassembly process planning is to develop procedures and software tools for disassembly strategies and disassembly system configurations [60]. The following steps were suggested in the works [58-62] in the design of a disassembly system plan:

- Input and output product analysis. During the first phase, reusable, important, and hazardous components and materials are specified. Optimum disassembly is defined after preliminary cost analysis.

- Assembly analysis. Attachment components, part hierarchy, and previous assembly sequences are analyzed during the second phase.

- Uncertainty issues analysis. Defective parts or joints in the incoming material or product upgrading/downgrading during use may cause disassembly instability and damage to disassembly.

- Determination of the dismantling strategy. The final phase determines whether non-destructive or destructive disassembly is going to be used.

Disassembly implementation requires tools that are highly efficient and versatile. In their paper, Feldmann et al. [63] illustrated some patented disassembly methods, one of the most interesting of which employed robots. Despite the potential for sophisticated automated disassembly of electronic equipment, there are only a few pilot projects related to keyboards, monitors and PCBs, and machines themselves do not have an automatic solution [64].

Selective disassembly (dismantling) is an important mechanism in the practice of WPCB recycling since: (1) Reuse of components is a priority; (2) disassembly of hazardous components is essential; (3) valuable products and high-quality materials, such as electronic components, cables, and plastics engineering, are further dismantled to simplify the subsequent recovery of materials.

\subsection{Mechanical Recycling Techniques}

Although all recycling technologies have expense, performance, and environmental hazard disadvantages, mechanical recycling is used profitably to obtain high-quality products, replacing virgin polymers and thereby reducing environmental impacts and preventing resource depletion [65]. It is generally regarded as the best waste management choice for PCBs. The market value of recycled materials from PCBs depends considerably on their purity, degree of decontamination and homogeneity [66], and strictly relates to the mechanical-recycling method effectiveness and to the polymer-classification phase.

This process may nonetheless prove challenging [67], because of the heterogeneous composition of PCB waste. For instance, bioplastics, substituted for traditional plastics, may be wrongly mixed with plastic waste instead of wet waste, thus 'polluting' the plastic waste stream. Some authors consider that mechanical recycling usually requires four treatment steps: (1) Cutting/shredding, to reduce particle size and to obtain a suitable shape for further processing; (2) separation in dry conditions, to eliminate impurities such as paper, dust, and other non-plastic materials; (3) polymer classification, to separate polymers per type; and (4) extruding, to homogenize the particle size of single-polymer plastics [68].

Currently, the techniques used in polymer recovery plants are most commonly based on flotation processes, density differences, electrostatic forces, and optical properties $[65,69,70]$. 
Other authors classify the mechanical recycling processes as in [71]:

- Washing, drying, and comminution. The disassembled materials from PCBs are washed for the removal of adhered impurities and dried. This process minimizes the particle surface contamination that could affect the reproducibility and efficiency of the tribo-charging mechanism [72]. The polymers are then ground in a knife mill. These activities result in wastewater (from the washing process) and dust, noise, and vibrations (from the grinding process). Therefore, further measures are required in order to reduce the environmental impact.

- Sieving. The particle size directly affects the tribo-electrostatic separation [73]. Thus, a granulometric separation is carried out, using sieves coupled to a vibratory agitator. The environmental impact thereof consists of sound, vibrations, and dust.

- Secondary washing and drying. Disassembled PCB particles can acquire surface charges during the comminution and sieving processes. This affects the charging efficiency as well as the quality and quantity of products resulting from the overall process [74]. One way to neutralize this parasitic charging is to apply subsequent washing and drying, in order to neutralize the disassembled PCB particles. Hence, the environmental impact is diminished to wastewater and drying energy consumption only.

\subsection{Electro-Mechanical Separation Methods}

Mechanical separation and electrical-conductivity (or resistivity) separation (such as eddy current separation), electrostatic separation, corona electrostatic separation, and tribo-electrical separation have been developed as effective techniques for isolating other components (non-ferrous metals and plastics) from the WEEE [75]. Table 2 shows the main characteristics of these processes.

Table 2. Electro-mechanical separation processes [57,75].

\begin{tabular}{|c|c|c|c|c|}
\hline Processes & $\begin{array}{l}\text { Separation } \\
\text { Criteria }\end{array}$ & Principles of Separation & Sorting Task & $\begin{array}{c}\text { Workable Particle } \\
\text { Size Range }\end{array}$ \\
\hline $\begin{array}{c}\text { Shredding, } \\
\text { washing, sieving }\end{array}$ & $\begin{array}{l}\text { Shredding: } \\
\text { Mechanical forces. } \\
\text { Sieving: Vibratory. }\end{array}$ & $\begin{array}{l}\text { Washing: To remove the } \\
\text { adhered impurities. } \\
\text { Sieving: Using sieves } \\
\text { coupled to a vibratory } \\
\text { agitator. }\end{array}$ & $\begin{array}{l}\text { Shredding: Crushing } \\
\text { and grinding. } \\
\text { Washing: Separation the } \\
\text { impurities from the } \\
\text { useful material. } \\
\text { Sieving: Particle size } \\
\text { separation. }\end{array}$ & $3-5 \mathrm{~mm}$ \\
\hline $\begin{array}{l}\text { Magnetic } \\
\text { separation }\end{array}$ & Magnetic field. & $\begin{array}{l}\text { The use of magnets to } \\
\text { separate magnetic } \\
\text { materials from mixtures. }\end{array}$ & $\begin{array}{l}\text { Separation ferromagnetic } \\
\text { metals from non-ferrous } \\
\text { metals and other } \\
\text { non-magnetic waste. }\end{array}$ & $3-5 \mathrm{~mm}$ \\
\hline $\begin{array}{l}\text { Eddy current } \\
\text { separation }\end{array}$ & $\begin{array}{c}\text { Electric } \\
\text { conductivity and } \\
\text { density. }\end{array}$ & $\begin{array}{l}\text { The use of a powerful } \\
\text { magnetic field to } \\
\text { separate non-ferrous } \\
\text { metals. }\end{array}$ & $\begin{array}{l}\text { Non-ferrous } \\
\text { metal/non-metal } \\
\text { separation. }\end{array}$ & $>5 \mathrm{~mm}$ \\
\hline $\begin{array}{l}\text { Corona } \\
\text { electrostatic } \\
\text { separation }\end{array}$ & $\begin{array}{c}\text { Electric } \\
\text { conductivity. }\end{array}$ & $\begin{array}{l}\text { Different charges of } \\
\text { particles resulting in } \\
\text { different forces between } \\
\text { particles. }\end{array}$ & $\begin{array}{l}\text { Metal/non-metal } \\
\text { separation. }\end{array}$ & $\begin{array}{l}0.1-5 \mathrm{~mm}(10 \mathrm{~mm} \\
\text { for laminar } \\
\text { particles })\end{array}$ \\
\hline $\begin{array}{l}\text { Triboelectrostatic } \\
\text { separation }\end{array}$ & Dielectric constant. & $\begin{array}{l}\text { Tribo-charge with } \\
\text { different charges (+ or }- \text { ) } \\
\text { of the components' force } \\
\text { directions. }\end{array}$ & $\begin{array}{l}\text { Separation of plastics } \\
\text { (non-conductors). }\end{array}$ & $<5(10) \mathrm{mm}$ \\
\hline
\end{tabular}

\subsubsection{Shredding, Washing, and Sieving}

Shredding/comminution involves decreasing the particle size $(3-5 \mathrm{~mm})$ of the material for subsequent processing. At the moment, different machines, metal shredders, hammers, and knife mills are used to crush and grind the WITTE $[3,76]$. The benefits include faster automated systems, lower public health and safety risks, higher performance, and a lower volume for transportation. The issues 
include product loss (up to $40 \%$ ) as dust [53], increased investment in assets, and a reduced level for later operations. Washing eliminates toxic materials to improve the efficiency of metal extraction [77].

Different types of materials can be isolated from WITTE after shredding by various separation methods, density separation, and forth flotation to separate metals and plastics in the mixture. Figure 5 shows an example of the process flow diagram of the WITTE shredding and separation system [16,78].

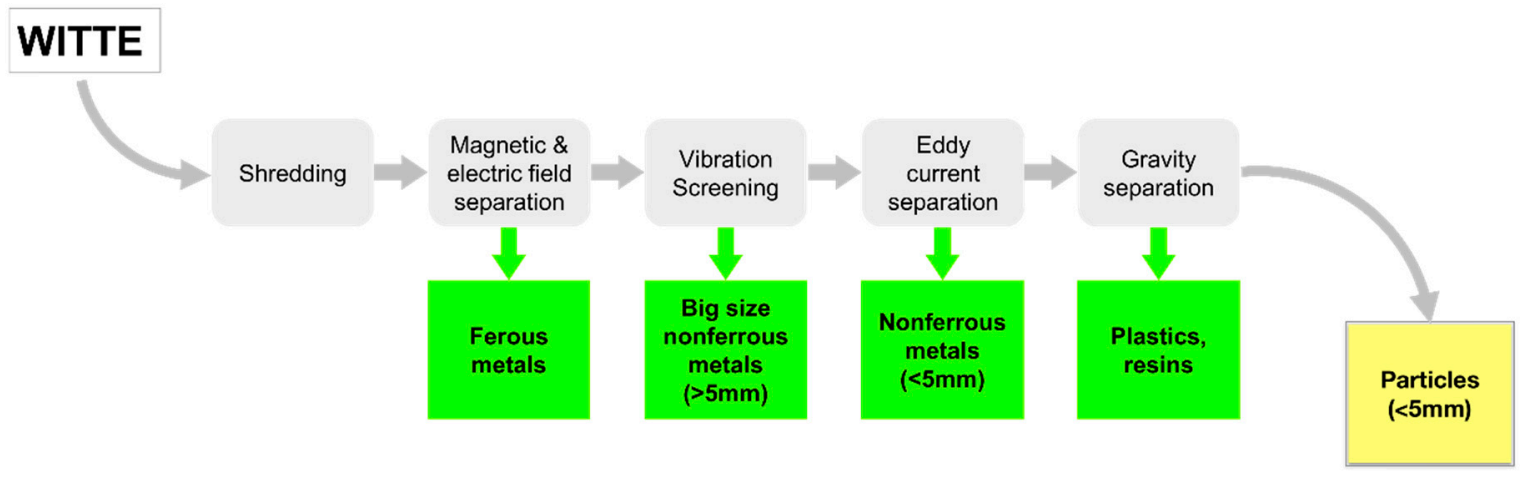

Figure 5. Flow diagram of the shredding and separation process.

"High grade PCBs" (i.e. PCI cards, motherboards, hard drive PCBs, memory modules), ceramic CPUs, and so forth can also be bulk shredded in order to separate the ferrous metals from the reduced size scrap. Nonetheless, due to different types of products of electronic components, like metals, plastics and resins, they can mix during the pre-processing stages (i.e. shredding, pulverization), leading to some recycling process dilution or technical restrictions [79]. Unselective fine shredding may result in the loss of valuable compounds [80], including multiple rare and precious metals that can be found in electronic components (in particular PCBs). These losses occur during shredding as a result of dispersion and "mass-relevant" contamination of precious metals with base metals, ferrous metals, and plastics. "Lower-grade PCBs" and power boards typically have a high content of $\mathrm{Cu}$, $\mathrm{Al}, \mathrm{Fe}$, and steel, but a very low or zero ratio of precious metals [48]. Therefore, shredding, gravity, magnetic, and/or electrical field separation processes are recommended for ferrous metals, $\mathrm{Cu}$, and $\mathrm{Al}$ separation [81]. "Lower grade PCBs" and scrap metals are often processed in a pyrometallurgical recovery plant in order to extract the base metals [82].

\subsubsection{Magnetic Separation}

Magnetic separation is commonly implemented to separate non-ferrous metals and other non-magnetic waste from ferromagnetic metals [83]. During the last decade, substantial progress has been made in developing and running high-intensity magnetic field separators, by the introduction of permanent magnets from rare earth alloys. The latest generation of permanent magnets can deliver very high field strengths.

The magnetic separation process can be used to separate the ferrous metal materials present in the dissembled PCB shredder mixture from those that are less or nonmagnetic [84]. Typically, electromagnetic crossbelt separators are employed to recover materials such as galvanized steel, iron, and tin-coated steel, and magnetic materials such as electrical transformers and chip coils [85]. Stainless-steel particles in the shredded remains are poorly magnetic and can be sorted using a strong magnetic field. The magnetic separation method has a major drawback associated with the attachment of non-ferrous particles to the ferrous materials. This decreases the process productivity. Besides magnetic material separation, recently developed processes like vertical vibration systems are widely utilized to separate metals and plastics from WEEE [86]. For example, vertical vibration systems improve the plastics separation from heterogeneous mixtures, like PCB waste metals [87]. 


\subsubsection{Eddy Current Separators}

Eddy current separators are ideal for separating large amounts of non-ferrous parts from WEEE and are particularly suitable for handling coarse-sized feeds. Eddy current separation, in addition to electrostatic separation [88,89], can be useful for concentration of non-ferrous metals like Cu or $\mathrm{Al}$ from the waste particle sizes between 2 and $50 \mathrm{~mm}$ [90]. As Al has the highest ratio of electrical conductivity/density value $\left(13.1 \times 10^{3} \mathrm{~m}^{2} / \Omega \cdot \mathrm{Kg}\right)$, with eddy current separators, it can be easily separated [91]. Eddy current separation can be applied for PCB waste as $\mathrm{Al}$ is $2.8 \mathrm{wt} . \%$ of the total PCB waste board [92,93]. Despite that, eddy current separation does not allow the separation of stainless steel, glass, and plastic contained in the waste mixture, since these materials have an extremely low electrical conductivity/density ratio. For this, it is impossible to isolate metals like $\mathrm{Cu}$ and $\mathrm{Al}$ from plastic insulation, like PVC and PE, in the waste mixture. Different sensors can, therefore, be used to distinguish different streams. For example, infrared sensor scanning is used to identify plastics, while glass is detected by optical sensor scanning [94].

Figure 6 shows materials that are detachable using eddy current separators. It is evident that $\mathrm{Al}$ is the easiest to separate, while stainless steel, plastic, and glass have a zero value for the conductivity/density ratio, meaning that eddy current separators are not applicable [1].

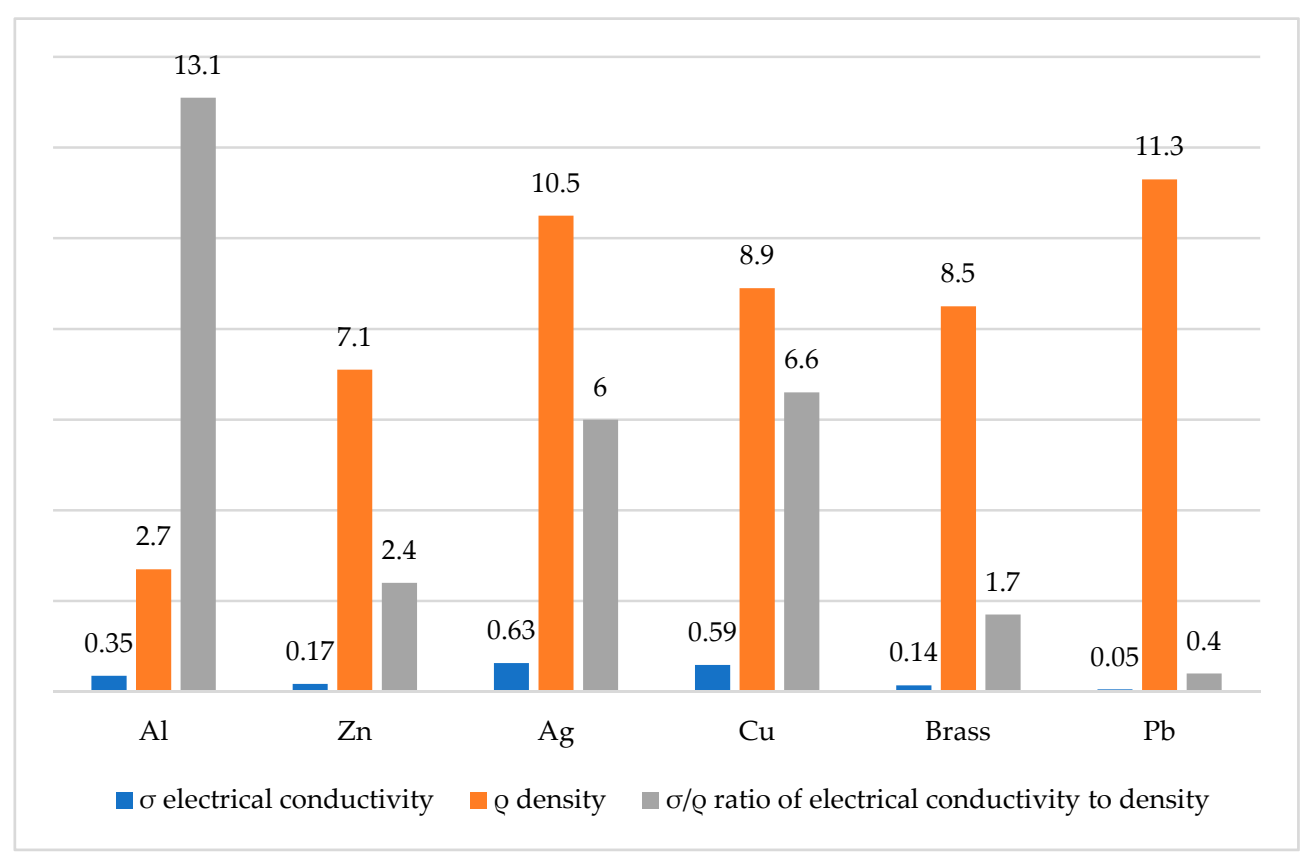

Figure 6. Materials that can be separated by an eddy current separator, and their properties: $\sigma$-electrical conductivity, $\left[10^{-8} / \Omega \mathrm{m}\right] ; \rho$-density, $\left[10^{3} \mathrm{~kg} / \mathrm{m}^{3}\right] ; \sigma / \rho$-ratio of electrical conductivity to density, $\left[10^{3} \mathrm{~m}^{2} / \Omega \mathrm{kg}\right][1]$.

Density-based separation and eddy current separation of non-ferrous metals are not recommended for the separation of precious metals, as significant losses will result [80]. Besides, prior to shredding, the large-sized metals (i.e., $\mathrm{Cu}$ or $\mathrm{Al}$ heatsinks, iron or steel films) must be removed from "higher-grade PCBs".

\subsubsection{Corona Electrostatic Separator}

Corona's process of electrostatic separation is utilized to isolate metals (including non-ferrous metals) from a heterogeneous mixture of enclosed plastics.

Based on the extreme density and electrical conductivity differences between metallic and nonmetallic materials $[38,95]$, Corona electrostatic separation is considered a promising method for metal extraction from pulverized WPCBs [96]. The metals and non-metals could be separated by 
electrostatic corona separation with good performance under the particle size condition of WPCBs, if they are between 0.6 and $1.2 \mathrm{~mm}$. [97].

However, the Corona effect can generate toxic compounds such as nitrogen oxide and ozone. A roll-type corona electrostatic separator has been effectively employed as an electrostatic separator to isolate ABS polymer fractions from the metallic particles collected from the waste stream of crushed PCBs [98]. The process is used, for example, in the mechanical recycling of PCB waste, because it involves specific metallic implants [91].

The performance of Corona separation is determined by many factors [99], such as the use of a high voltage, electrode configuration, feed frequency, size of granules, roll speed, and ambient conditions [100]. The roll-type separator can be applied to recycle metals and plastics from waste PCBs, as a result of these variables' interactions.

The middling products are a downside of the Corona separation. With their high metal content, they require further separation. To decrease the middling products, the following problems must, therefore, be addressed:

- Middling materials of the separation system and additional treatment. Due to the feeding process, non-uniform electrical field, and space charge distribution, a considerable number of particles don't gain sufficient charge and goes in to the middling products. Furthermore, certain unintended factors, such as changes in ambient conditions, often increase the middling products.

- Nonconductive material impurity and additional treatment. Since the particle mixture consists mainly of nonmetals, certain metals are covered with nonmetals. Such particles bind to the sheet, move with it, and eventually goes with the particles that are not conductive. This contributes not only to metal loss, but also to the impurity of the non-conductive materials. If the particle dimensions are $<0.6 \mathrm{~mm}$, it is possible to achieve complete separation between metals and non-metals for comminuted PCB waste [101].

- Stability of the separation process. For the following reasons, the results are unstable [102]: The metal concentration variability in the feeding material; the temperature and humidity fluctuations; the electrostatic separation sensitivity to the particle size; and the accumulation of dust on the corona electrode. For example, under laboratory conditions, the granule mixture can be sorted into several size groups. Nevertheless, this is not valid in industrial applications, where particles belonging to different size groups are always a concern.

- Agreement between efficiency of production and quality of separation. Higher feed rates and higher roll speeds are required to increase the production capacity. However, a higher roll speed could lead to poor quality of separation [103] due to the creation of a large quantity of middling products.

- Feeding granule mixture superficial moisture. The mixture of feeding granules absorbs the moisture in the area.

\subsubsection{Triboelectrostatic Separation}

Interest in triboelectrostatic separation is increasing because it appears to be the first dry method that does not require wastewater treatment processes to detach particles of similar density and electrical resistivity [57].

The basic principle of triboelectrostatic separation is the selective sorting of a polarized or charged species under an electric field based on their surface charging characteristics [104,105]. The surface of plastic materials is charged by frictional electrification (or tribocharging) by rubbing polymeric materials together $[106,107]$. Through tribocharging, the different polymeric materials develop opposite polarities and can be deflected and separated in the electrical field.

Researchers have demonstrated many clear benefits of triboelectric electrostatic separation for the processing of plastic waste from PCBs, such as particle form independence, low energy consumption, and high efficiency $[35,108]$. This method is ideal for $0.1-5 \mathrm{~mm}[109,110]$ fine particles. However, most studies address virgin plastics from urban solid waste, rather than post-consumer products [111]. 
The triboelectric polymers sequence [112] is an important separation indicator. The sequence explains the polarities gained from the charged particles of plastic, for instance:

(-) -PE-PS-PC-PVC-ABS-PP- (+).

In detaching non-conducting materials from WPCBs, triboelectrostatic separation can be applied [113]. It provides a relatively wide range of particle size processing, which is particularly suitable for WPCB granular plastic waste [74].

A complete separation of nonmetals and metals can only be accomplished for crushed WPCBs, if the granule size is less than $0.6 \mathrm{~mm}$ [101]. Triboelectrostatic separation allows the recuperation of metals with high conductivity like $\mathrm{Al}$ and $\mathrm{Cu}$ (e.g., cable and wires waste) from the mixtures [114]. However, a large volume of metals, particularly conductive materials, is found in materials that are not conductive [115]. Through the triboelectrostatic method, nonmetal particles like plastics in PCBs recuperated from WEEE can be separated. PVC and rubber can be recovered from scrap cables using a simple and inexpensive triboelectrostatic technique in which these materials are deviated into the positive/negative electrode $[116,117]$.

Studies show that parameters such as particle size and relative humidity affect waste plastic granules ' charging properties. The triboelectrostatic technique also applies to polymers, like high-impact polystyrene and acrylonitrile butadiene styrene, that are identified most commonly in PCBs waste [117,118].

A tribo-aero-electrostatic separator was introduced in [118] as a process to retrieve HIPS and ABS contained in WITTE plastics. A modified tribo-aero-electrostatic separator can be utilized to separate waste plastic granules $(2-5 \mathrm{~mm})$ with high efficiency. For an effective separation from waste of PA and PC plastic components, a tribo-aero-electrostatic separator was used in [119]. It may also be useful to separate the highly enriched PVC fraction from cable waste [120].

The tribo-aero-electrostatic method has been indicated as highly effective for isolating plastics from a mixture of $20 \mu \mathrm{m}$ average size recycled ABS (separated from WEEE), PVC weak in carbon and pure PVC [121].

Pneumatic triboelectrostatic separation uses pipelines to transport the waste particles. The waste particles collide with the inner wall of the tube and become positively and negatively charged. Next, the particles are injected into a separation reactor where an electric field is applied to separate them [122].

\subsection{Gravity Separation}

Separators of density, such as air tables, air cyclones, and centrifugal separators, are used to extract base metals from nonmetal fractions such as $\mathrm{Cu}, \mathrm{Au}$, and Ag. Particle separation based on density [57], such as sink-float separation [123], is also used to extract metals from scrap PCB non-metallic materials. Several techniques are used to separate heavy materials from light ones. The separation is performed as a function of the density difference in waste particles, as presented in Table 3.

Different materials are separated by their relative motion in response to the force of gravity and possibly to other forces, such as water or air resistance. A particle's movement into a fluid depends on the density, size, and shape of the particle, with large particles being more greatly affected than small ones [124]. In practice, it is important to reduce the effect of size, and it is, therefore, necessary to control the approximate dimension of feeds in gravity processes. 
Table 3. Density separation processes utilized in non-metal-metal separation [57].

\begin{tabular}{|c|c|c|c|c|c|c|}
\hline $\begin{array}{c}\text { Density Separation } \\
\text { Process }\end{array}$ & $\begin{array}{l}\text { Workable Piece } \\
\text { Sizes (mm) }\end{array}$ & $\begin{array}{l}\text { Plastics } \\
\text { Waste }\end{array}$ & $\begin{array}{l}\text { Aluminum } \\
\text { Scrap }\end{array}$ & $\begin{array}{l}\text { Cable } \\
\text { Scrap }\end{array}$ & $\begin{array}{l}\text { Electronic } \\
\text { Scrap }\end{array}$ & $\begin{array}{l}\text { Light Steel } \\
\text { Scrap }\end{array}$ \\
\hline $\begin{array}{c}\text { Sink-float } \\
\text { separation-Liquids } \\
\text { Sink-float } \\
\text { separation-Gravity } \\
\text { separator }\end{array}$ & $5-150$ & & & & & \\
\hline $\begin{array}{c}\text { Sink-float } \\
\text { separation-Hydrocyclone }\end{array}$ & $<50$ & & & & & \\
\hline $\begin{array}{c}\text { Sink-float } \\
\text { separation-Aero-chutes } \\
\text { Sink-float }\end{array}$ & $0.7-3$ & & & & & \\
\hline $\begin{array}{l}\text { separation-Fluidized bed } \\
\text { trough separation }\end{array}$ & $0.7-5$ & & & & & \\
\hline Sorting by hydraulic jigs & $2-20$ & & & & & \\
\hline Sorting by pneumatic jigs & $<3$ & & & & & \\
\hline Sorting in Aero-chutes & $0.6-2$ & & & & & \\
\hline Sorting in Aero-tables & $<4$ & & & & & \\
\hline $\begin{array}{l}\text { Up-stream hydraulic } \\
\text { separation }\end{array}$ & $5-150$ & & & & & \\
\hline $\begin{array}{l}\text { Up-stream pneumatic } \\
\text { separation }\end{array}$ & $<300$ & & & & & \\
\hline
\end{tabular}

\subsection{Chemical Recycling Techniques}

The economically mineable $\mathrm{Au}, \mathrm{Ag}$, and $\mathrm{Cu}$ reserves will be exhausted in the next fifty years [125]. Simultaneously, the metal content of WPCBs will surpass the availability of natural resources. Consequently, WPCBs will become an increasingly attractive secondary source of metals, contributing to natural resource conservation [126,127]. The main targets for recycling WPCBs are precious metals, followed by $\mathrm{Cu}, \mathrm{Ni}$, and other base metals [128].

The precious and base metal concentration in a WPCB is determined by quantitative and chemical analysis, which gives its actual recycling quality. The metal composition in metal recycling facilities is generally measured using inductively coupled plasma atomic emission spectroscopy (ICP-AES) [129,130].

One of the chemical recycling techniques is bromide leaching of WPCBs. Bromide is a hazardous material, although a few studies claim it is harmless [131]. Because of the addition of brominated flame retardants, the bromide concentration in PCBs is relatively high. After the decomposition of brominated flame retardants in the recycling process, bromide persists in several forms of bromide or bromorganic compounds, including $\mathrm{HBr}$, bromomomethane, and bromophenol. Bromide can cause health problems, particularly $\mathrm{HBr}$, which is retained by the human body, and is difficult to degrade.

Nonetheless, the recovery of precious metals can only be achieved after primarily leaching of the base metals; due to the high base metal content (e.g., $\mathrm{Cu}>15 \%$ ), the process involves extensive use of leaching solutions. In [132], the preliminary steps necessary to separate precious metals from base metals and other complex WPCB materials are presented. The metals can be extracted selectively by efficient hydrometallurgical methods, such as $\mathrm{Cu}$ and $\mathrm{Au}$ recovery [133,134]. Issues such as increasing the leaching level and selectivity while reducing the use of reagents [135] must be discussed further. Strict environmental regulations have prompted further research into WPCB recycling, fostering the development of environmentally friendly and energy-saving processes [136]. 


\subsection{Electrochemical Processes}

Electrochemical processes can reduce the use of polluting reagents [137], because electrons are a "clean reagent". They have a strong compatibility with the environment, high energy efficiency, and can be used with minimal involvement of auxiliary materials. Using electrochemical methods to leach metals from WPCBs can reduce reagent consumption and recover valuable metals with minimal loss [138]. The use of reagents can be significantly reduced by using direct or controlled electrochemical oxidation for the dissolution of metals. In addition, in combination with metal oxidation, electro-extraction is an alternative method to remove the metals from leaching solutions [16]. The two processes can be performed in a single cell [139]. During the oxidation of water to $\mathrm{O}_{2}$, the production of protons at the anode can sustain low-pH environments for dissolution.

Electrochemically produced chlorine $\left(\mathrm{Cl}_{2}\right)$ is a powerful oxidizer that can dissolve most metals, including $\mathrm{Au}$. The leaching rate, however, is limited by $\mathrm{Cl}_{2}$ solubility [140]. The use of $\mathrm{Cl}_{2}$ as an oxidizer has the disadvantage of creating a working hazard and material corrosion. In order to selectively dissolve the less noble metals, another oxidizer $\left(\mathrm{Fe}^{3+}\right)$ has been proven to be a less-hazardous alternative. It has been deployed in the low-temperature electrochemical recovery of metal from ore [141,142]. This method has shown promising results in terms of having a low impact on the environment [138], low energy consumption, and a high recovery of base metals, thus leaving Au and Pd intact for processing in separate stages. However, more research is needed to improve leaching kinetics, increase the solid to liquid ratio in the leaching treatment, and assess the effect of base metal extractions and precious metal recovery. The electrochemical recovery method significantly reduces the consumption of chemicals and production of waste. This method allows oxidant and leaching solution reuse simultaneously with the extraction of base metals [143].

A recovery process for $\mathrm{Cu}$ from electrochemically liberated and uncomminuted WPCBs has been proposed in [16]. It involves two steps: The removal of the solder mask from the surface of the WPCBs by chemical treatment in concentrated $\mathrm{H}_{2} \mathrm{SO}_{4}$, followed by anodic dissolution of metals with simultaneous electrodeposition of a high-Cu-content alloy. The results show that the solder mask can be removed in concentrated $\mathrm{H}_{2} \mathrm{SO}_{4}$ without metal dissolution. $\mathrm{Cu}$ has been recovered by cathodic electrodeposition in a galvanostatic mode, at high efficiency $(100 \%)$, using a Pb cage with graphite granules as the anode current collector. The specific energy consumption for the cathodic deposit was WS $=1.06 \mathrm{KWh} / \mathrm{kg}$, with $98 \% \mathrm{Cu}$ content [144].

In a different study, in the presence of chloride ions without electrochemical oxidation, $\mathrm{Cu}^{2+}$ was shown to oxidize the $\mathrm{Cu}$ in metal powders to form $\mathrm{CuCl}_{2}{ }^{-}$. Then, $\mathrm{CuCl}_{2}{ }^{-}$was oxidized by oxygen into $\mathrm{CuSO}_{4}$. Consequently, the leaching rate of $\mathrm{Cu}$ reached $100 \%$. The chloride ion was electro-oxidized into $\mathrm{ClO}^{-}$, which oxidized $\mathrm{CuCl}_{2}{ }^{-}$into $\mathrm{CuSO}_{4}$, and $\mathrm{ClO}^{-}$was reduced to $\mathrm{Cl}^{-}$. The leaching solution is concentrated to crystallize $\mathrm{CuSO}_{4} \cdot 5 \mathrm{H}_{2} \mathrm{O}$, and the resulting solution is reused to leach a $\mathrm{Cu}$ metal powder [145].

Using the $\mathrm{H}_{2} \mathrm{O}_{2}-\mathrm{HCl}$ leaching system for $\mathrm{Au}$ dissolution and the rotating disk electrode for $\mathrm{Au}$ electrowinning, Au recovery from secondary WPCBs streams can be performed with high efficiency and low environmental impact. The Au leaching process is more sensitive to the concentration of $\mathrm{HCl}$. Increasing the concentration of $\mathrm{HCl}$ reduces the specific consumption of $\mathrm{H}_{2} \mathrm{O}_{2}$ and $\mathrm{HCl}$, while increasing the concentration of $\mathrm{H}_{2} \mathrm{O}_{2}$ only improves the efficiency factor for the use of $\mathrm{HCl}$. The process of Au dissolution is carried out with the highest efficiency using concentrations of $5 \mathrm{M} \mathrm{H}_{2} \mathrm{O}_{2}$ and $5 \mathrm{M}$ $\mathrm{HCl}$. The electrowinning of Au from the leaching solutions with a rotating disk electrode resulted in the recovery of a high-purity Au deposit $(99.99 \mathrm{wt} \%$, for a current efficiency of $78.93 \%$ and a specific energy consumption of $0.648 \mathrm{kWh} / \mathrm{kg} \mathrm{Au}$ ) [146].

Recovery of $\mathrm{Cu}$ from WPCBs by direct electrochemical oxidation or by mediated electrochemical oxidation by the redox couple $\mathrm{Fe}^{3+} / \mathrm{Fe}^{2+}$ [138] implies $\mathrm{Cu}$ dissolution with simultaneous electro-extraction from the resulting leaching solutions. The first process uses direct electrochemical oxidation, while the second process uses the $\mathrm{Fe}^{3+} / \mathrm{Fe}^{2+}$ redox pair to achieve $\mathrm{Cu}$ dissolution by means of mediated electrochemical oxidation. 
It is possible to produce pure metal and its salt by using electrolysis and evaporation, followed by crystallization. The novel metallurgical pyro-hydro hybrid method is stated to consist of pyrolysis-beneficiation-leaching-solvent extraction for metal recovery from scrap PCBs. The process that has been developed is cleaner and more environmentally friendly, in line with the concept of zero waste generation [147].

\subsection{Thermal Recycling Methods}

Thermal recycling (incineration) methods are utilized to extract energy from WEEE plastics, like water, steam, or electricity. This process focuses particularly on heterogeneous plastics that are pretreated, or polluted, and cannot be reused efficiently by any other process. Thermal recycling of plastic waste occurs in thermal recycling plants using combustion chambers, incinerators, boilers, or large industrial plants [148-150]. These provide a convenient energy production option, due to the high calorific value of plastics- $7375 \mathrm{Kcal} / \mathrm{Kg}$, compared to urban solid waste, which is $3450 \mathrm{Kcal} / \mathrm{Kg}$ [151] — comparable to common fuels [113,152]. Plasmatron plasma reactor technology applied for PCBs thermal recovery has shown that $117 \mathrm{~kW}$ of energy can be produced using $30 \mathrm{~kg} / \mathrm{h}$ waste PCBs [153]. The reactor used only $66 \mathrm{~kW}$ to operate. Thermal recycling techniques can also be utilized to recycle the bromine-containing flame retardants. WEEE plastics contain brominated flame retardants. Ferric Oxide $\left(\mathrm{Fe}_{2} \mathrm{O}_{3}\right)$ can be used in thermal recycling of brominated flame retardants, (tetrabromobisphenol A), because can fix bromine emitted [154]. Waste plastic thermal processing produces by-products like ash (bottom and fly ash), greenhouse gases, and dangerous substances (antimony, mercury, tin, halogenated compounds). These by-products raise concerns for the environment and health [155]. Adding advanced emission control devices, toxic gas trapping systems, and combustion chamber modifications will reduce environmental threats to some degree [156].

\subsubsection{Pyrolysis Process}

Pyrolysis processes for WPCBs have been reported in many scientific publications: Vacuum pyrolysis [157], nitrogen supply pyrolysis, nitrogen supply oxidative pyrolysis, and oxygen supply [82]. Evangelopoulos et al. [158] used thermogravimetric analysis (TGA) and analytical pyrolysis (Py-GC/MS) to investigate the pyrolytic activity of $\mathrm{PCB}$ waste fractions at a temperature range of $400{ }^{\circ} \mathrm{C}$ to $900{ }^{\circ} \mathrm{C}$. The experimental results indicate that the $\mathrm{PCBs}{ }^{\prime}$ chemical composition and relatively high ash content are strongly linked to the high metal and ceramic content quantities. PCB pyrolysis reveals a range of aromatic compounds like bisphenol A, styrene, phenol, methylstyrene, bromophenol, together with non-aromatic compounds like bromomomethane and acetone. These are strongly associated with the original composition of PCBs. In a study [157], under the conditions of a fixed-bed reactor, vacuum pyrolysis of WPCBs was performed. The result was 99.50 percent $\mathrm{Cu}$ extraction with a recovery quality of 99.86 percent based on the WPCBs ' total weight.

\subsubsection{Thermal Treatment}

The thermal decomposition method of "lower-grade" WPCBs is economically inefficient [159]. Fly ashes are formed by thermal decomposition of the non-metallic component of WPCBs. Fly ash cannot be recycled; therefore, it must be disposed of in landfill. Fly ashes can contain scraps of metal, base metals, and traces of precious metals [160].

According to [160] and [161], in the presence of air, the thermal treatment process of WPCBs may improve the recovery efficiency of metals before leaching. In general, WPCB components (i.e., IC chips, connectors, and small capacitors) need to be exposed to chemical solutions to produce a maximum leaching rate for recovery. During a further hydrometallurgical leaching process, thermal decomposition of higher-grade WPCBs in an aerobic environment can increase the recovery rate of precious and base metals [160]. The thermal treatment process is only suitable for the recovery of valuable and base metals from high-grade WPCBs from WITTE [16]. 
Thermal treatment followed by hydrometallurgical processes shows the most promising results among the environmentally friendly production processes that allow metal recovery and efficient toxic compound treatment. They ensure that metals are selectively separated from non-metallic parts of WPCBs in an eco-friendly manner [162]. Nevertheless, the use of high-leaching solution volumes in certain hydrometallurgical processes leads to large quantities of waste [163].

\section{Conclusions}

This review paper focuses on the recycling processes of high-economic-value materials arising from IT and telecommunications equipment waste printed circuit boards (WPCBs).

Soon, the dramatically increasing amount of IT and telecommunications equipment waste will mean that disassembly automation, especially for IT and telecommunications equipment, will be required worldwide. Some pilot projects are currently being implemented in the form of fully automated single-purpose solutions. The main problem is the aggregation and transport to one place of a high enough quantity of items.

WITTE is highly heterogeneous and complex in element and material form, size, and shape. A detailed analysis should, therefore, be carried out with the goal of better understanding this particular waste stream.

WITTE must be shredded into tiny, even, fine particles, usually less than $10 \mathrm{~mm}$ in size, to be separated. The reuse of WITTE involves the mechanical separation of fine particles.

The methods of electromechanical separation include shredding, washing, and sieving. The methods of magnetic separation include eddy current separation, corona electrostatic separation, and triboelectrostatic separation, which are important processes developed to reuse various types of scrap materials. These methods are very well adapted to WITTE reuse due to the increase in the volume of WITTE and the variety of their compositions.

Using chemical and electrochemical recycling techniques to recover critical materials and precious metals could be a step towards achieving a circular economy. From reviewing the literature concerning recycling of WITTE, the contribution of precious metals is so high that it influences half of the economic recovery potential. Even the recycling of materials with low economic value can offer relevant contributions if they are available in enough quantities.

For treating WPCBs, individual treatment is insufficient since WPCBs are comprised of diverse materials with various intrinsic values. An integrated approach, encompassing disassembly, mechanical, and hydrometallurgical methodologies, should be developed. More effort is required in the development of materials for downstream applications and nontoxic feedstock for pyrolytic refining.

Toxic materials should be eliminated from PCB manufacturing processes. In order to be completely environmentally friendly, PCBs should only contain recyclable parts and recoverable metals.

Author Contributions: H.V.: Concept, writing, editing, figures provision, images provision, general supervision linguistic revision; A.-E.T.: bibliographic research, figures provision images provision, editing. M.P.: Writing, editing, figures provision, images provision, general supervision. All authors have read and agreed to the published version of the manuscript.

Funding: This research received no external funding.

Acknowledgments: This work was supported within the research program PN-III-P1-1.2-PCCDI-2017-0652, project NR. 84PCCDI - 01/03/2018 TRADE-IT.

Conflicts of Interest: The authors declare no conflict of interest.

\section{References}

1. Hazra, A.; Das, S.; Ganguly, A.; Das, P.; Chatterjee, P.; Murmu, N.; Banerjee, P. Plasma Arc Technology: A Potential Solution toward Waste to Energy Conversion and of GHGs Mitigation. In Waste Valorisation and Recycling; Springer: Singapore, 2019; pp. 203-217. [CrossRef]

2. Ning, C.; Lin, C.S.K.; Hui, D.C.W.; Mckay, G. Waste Printed Circuit Board (PCB) Recycling Techniques; Springer International Publishing: Basel, Switzerland, 2017; Volume 375. [CrossRef] 
3. Kumar, A.; Holuszko, M.; Espinosa, D.C.R. E-Waste: An Overview on Generation, Collection, Legislation and Recycling Practices. Resour. Conserv. Recycl. 2017, 122, 32-42. [CrossRef]

4. Suresh, S.S.; Bonda, S.; Mohanty, S.; Nayak, S.K. A Review on Computer Waste with Its Special Insight to Toxic Elements, Segregation and Recycling Techniques. Process Saf. Environ. Prot. 2018, 116, 477-493. [CrossRef]

5. Awasthi, A.K.; Hadi, P.F.; D'Adamo, I.; Li, J.; Rosa, P.; Terzi, S.; Wei, G.; Zeng, X. Modelling the correlations of e-waste quantity with economic increase. Sci. Total Environ. 2018, 613-614, 46-53. [CrossRef] [PubMed]

6. Baldé, C.P.; Forti, V.; Gray, V.; Kuehr, R.; Stegmann, P. The Global E-Waste Monitor-2017; United Nations University (UNU), International Telecommunication Union (ITU) \& International Solid Waste Association (ISWA): Bonn, Germany; Geneva, Switzerland; Vienna, Austria, 2017.

7. Liu, H.; Wu, X.; Dou, D.; Tang, X.; Leong, G.K. Determining Recycling Fees and Subsidies in China's WEEE Disposal Fund with Formal and Informal Sectors. Sustainability 2018, 10, 2979. [CrossRef]

8. Cucchiella, F.; D'Adamo, I.; Koh, L.; Rosa, P. A profitability assessment of European recycling processes treating printed circuit boards from waste electrical and electronic equipments. Renew. Sustain. Energ Rev. 2016, 64, 749-760. [CrossRef]

9. Awasthi, A.K.; Hasan, M.; Mishra, Y.K.; Pandey, A.K.; Tiwar, B.N.; Kuhad, R.C.; Gupta, V.K.; Thakur, V.K. Environmentally sound system for E-waste: Biotechnological perspectives. Curr. Res. Biotechnol. 2019, 1, 58-64. [CrossRef]

10. Reuter, M.A.; Hudson, C.; Van Schaik, A.; Heiskanen, K.; Meskers, C.; Hagelüken, C. UNEP. Metal Recycling: Opportunities, Limits, Infrastructure, A Report of the Working Group on the Global Metal Flows to the International Resource Panel; United Nations Environment Programme: Nairobi, Kenya, 2013.

11. Dwivedy, M.; Mittal, R.K. An Investigation into E-Waste Flows in India. J. Clean. Prod. 2012, 37, $229-242$. [CrossRef]

12. Needhidasan, S.; Samuel, M.; Chidambaram, R. Electronic Waste-An Emerging Threat to the Environment of Urban India. J. Environ. Health Sci. Eng. 2014, 12, 36. [CrossRef]

13. Betts, K.; Rajagopal, R.R.; Rajarao, R.; Sahajwalla, V.; Bernstad, A.; la Cour Jansen, J.; Aspegren, H.; Camelino, S.; Rao, J.; Padilla, R.L.; et al. Producing Usable Materials from E-Waste. Environ. Sci. Technol. 2008, 42, 6782-6783. [CrossRef]

14. Yu, J.; Williams, E.; Ju, M.; Yang, Y. Forecasting Global Generation of Obsolete Personal Computers. Environ. Sci. Technol. 2010, 44, 3232-3237. [CrossRef]

15. Cruz-Sotelo, S.E.; Ojeda-Benítez, S.; Jáuregui Sesma, J.; Velázquez-Victorica, K.I.; Santillán-Soto, N.; García-Cueto, O.R.; Concepción, V.A.; Alcántara, C. E-Waste Supply Chain in Mexico: Challenges and Opportunities for Sustainable Management. Sustainability 2017, 9, 503. [CrossRef]

16. Habib Al Razi, K.M. Resourceful Recycling Process of Waste Desktop Computers: A Review Study. Resour. Conserv. Recycl. 2016, 110, 30-47. [CrossRef]

17. Williams, E.; Kahhat, R.; Allenby, B.; Kavazanjian, E.; Kim, J.; Xu, M. Environmental, Social, and Economic Implications of Global Reuse and Recycling of Personal Computers. Environ. Sci. Technol. 2008, 42, 6446-6454. [CrossRef] [PubMed]

18. Kiddee, P.; Naidu, R.; Wong, M.H. Electronic Waste Management Approaches: An Overview. Waste Manag. 2013, 33, 1237-1250. [CrossRef]

19. Bernstad, A.; la Cour Jansen, J.; Aspegren, H. Property-Close Source Separation of Hazardous Waste and Waste Electrical and Electronic Equipment-A Swedish Case Study. Waste Manag. 2011, 31, 536-543. [CrossRef]

20. Steubing, B.; Böni, H.; Schluep, M.; Silva, U.; Ludwig, C. Assessing Computer Waste Generation in Chile Using Material Flow Analysis. Waste Manag. 2010, 30, 473-482. [CrossRef]

21. Kaya, M. Recovery of metals and nonmetals from electronic waste by physical and chemical recycling processes. Waste Manag. 2016, 57, 64-90. [CrossRef]

22. Duan, H.; Hou, K.; Li, J.; Zhu, X. Examining the Technology Acceptance for Dismantling of Waste Printed Circuit Boards in Light of Recycling and Environmental Concerns. J. Environ. Manag. 2011, 92, 392-399. [CrossRef]

23. Duan, H.; Li, J.; Liu, Y.; Yamazaki, N.; Jiang, W. Characterization and Inventory of PCDD/Fs and PBDD/Fs Emissions from the Incineration of Waste Printed Circuit Board. Environ. Sci. Technol. 2011, 45, 6322-6328. [CrossRef] 
24. Richter, H.; Lorenz, W.; Bahadir, M. Examination of Organic and Inorganic Xenobiotics in Equipped Printed Circuits. Chemosphere 1997, 35, 169-179. [CrossRef]

25. Faraji, F.; Golmohammadzadeh, R.; Rashchi, F. Fungal bioleaching of WPCBs using Aspergillus niger: Observation, optimization and kinetics. J. Environ. Manag. 2018, 217, 775-787. [CrossRef] [PubMed]

26. Becci, A.; Amato, A.; Fonti, V.; Karaj, D.; Beolchini, F. An innovative biotechnology for metal recovery from printed circuit boards. Resour. Conserv. Recycl. 2020, 153, 104549. [CrossRef]

27. Işıldara, A.; van Hullebusch, E.D.; Lenzd, M.; Laing, G.D.; Marra, A.; Cesaro, A.; Panda, S.; Akcil, A.; Kucuker, M.A.; Kuchta, K. Biotechnological strategies for the recovery of valuable and critical raw materials from waste electrical and electronic equipment (WEEE)—A review. J. Hazard. Mater. 2019, 362, 467-481. [CrossRef]

28. Ogunseitan, O.A.; Schoenung, J.M.; Saphores, J.-D.M.; Shapiro, A.A. The Electronics Revolution: From E-Wonderland to E-Wasteland. Science 2009, 326, 670-671. [CrossRef] [PubMed]

29. Fang, W.; Yang, Y.; Xu, Z. PM10 and PM2.5 and Health Risk Assessment for Heavy Metals in a Typical Factory for Cathode Ray Tube Television Recycling. Environ. Sci. Technol. 2013, 47, 12469-12476. [CrossRef]

30. Fu, J.; Zhang, A.; Wang, T.; Qu, G.; Shao, J.; Yuan, B.; Wang, Y.; Jiang, G. Influence of E-Waste Dismantling and Its Regulations: Temporal Trend, Spatial Distribution of Heavy Metals in Rice Grains, and Its Potential Health Risk. Environ. Sci. Technol. 2013, 47, 7437-7445. [CrossRef]

31. Song, Q.; Wang, Z.; Li, J.; Yuan, W. Life Cycle Assessment of Desktop PCs in Macau. Int. J. Life Cycle Assess. 2013, 18, 553-566. [CrossRef]

32. Man, M.; Naidu, R.; Wong, M.H. Persistent Toxic Substances Released from Uncontrolled E-Waste Recycling and Actions for the Future. Sci. Total Environ. 2013, 463-464, 1133-1137. [CrossRef]

33. Verma, H.R.; Singh, K.K.; Mankhand, T.R. Comparative Study of Printed Circuit Board Recycling by Cracking of Internal Layers Using Organic Solvents-Dimethylformamide and Dimethylacetamide. J. Clean. Prod. 2017, 142, 1721-1727. [CrossRef]

34. Hanafi, J.; Jobiliong, E.; Christiani, A.; Soenarta, D.C.; Kurniawan, J.; Irawan, J. Material Recovery and Characterization of PCB from Electronic Waste. Procedia-Soc. Behav. Sci. 2012, 57, 331-338. [CrossRef]

35. Yamane, L.H.; de Moraes, V.T.; Espinosa, D.C.R.; Tenório, J.A.S. Recycling of WEEE: Characterization of Spent Printed Circuit Boards from Mobile Phones and Computers. Waste Manag. 2011, 31, 2553-2558. [CrossRef] [PubMed]

36. Awasthi, A.K.; Li, J.; Koh, L.; Ogunseitan, O.A. Circular economy and electronic waste. Nat. Electron. 2019, 2, 86-89. [CrossRef]

37. Kumar, A.; Holuszko, M.E.; Janke, T. Characterization of the non-metal fraction of the processed waste printed circuit boards. Waste Manag. 2018, 75, 94-102. [CrossRef] [PubMed]

38. Huang, K.; Guo, J.; Xu, Z. Recycling of Waste Printed Circuit Boards: A Review of Current Technologies and Treatment Status in China. J. Hazard. Mater. 2009, 164, 399-408. [CrossRef] [PubMed]

39. Stone, R. Confronting a Toxic Blowback from the Electronics Trade. Science 2009, 325, 1055. [CrossRef] [PubMed]

40. Rios, P.; Stuart, J.A.; Grant, E. Plastics Disassembly versus Bulk Recycling: Engineering Design for End-of-Life Electronics Resource Recovery. Environ. Sci. Technol. 2003, 37, 5463-5470. [CrossRef]

41. Wang, J.; Xu, Z. Disposing and Recycling Waste Printed Circuit Boards: Disconnecting, Resource Recovery, and Pollution Control. Environ. Sci. Technol. 2015, 49, 721-733. [CrossRef]

42. Huang, J.; Chen, M.; Chen, H.; Chen, S.; Sun, Q. Leaching Behavior of Copper from Waste Printed Circuit Boards with Brønsted Acidic Ionic Liquid. Waste Manag. 2014, 34, 483-488. [CrossRef]

43. Franke, C.; Kernbaum, S.; Seliger, G. Remanufacturing of Flat Screen Monitors. In Innovation in Life Cycle Engineering and Sustainable Development; Brissaud, D., Tichkiewitch, S., Zwolinski, P., Eds.; Springer: Dordrecht, The Netherlands, 2006; pp. 139-152.

44. Isernia, R.; Passaro, R.; Quinto, I.; Thomas, A. The Reverse Supply Chain of the E-Waste Management Processes in a Circular Economy Framework: Evidence from Italy. Sustainability 2019, 11, 2430. [CrossRef]

45. Parajuly, K.; Wenzel, H. Product Family Approach in E-Waste Management: A Conceptual Framework for Circular Economy. Sustainability 2017, 9, 768. [CrossRef]

46. Becker, W.; Simon-Hettich, B.; Honicke, P. Toxicology and Ecotoxicology Investigations for Liquid Crystal and Disposal of LCDs; Merck brochure, Merck KGaA, Liquid Crystals Division and Institute of Toxicology 64271: Darmstadt, Germany, 2003. 
47. Bi, X.; Simoneit, B.R.T.; Wang, Z.; Wang, X.; Sheng, G.; Fu, J. The Major Components of Particles Emitted during Recycling of Waste Printed Circuit Boards in a Typical E-Waste Workshop of South China. Atmos. Environ. 2010, 44, 4440-4445. [CrossRef]

48. Oguchi, M.; Murakami, S.; Sakanakura, H.; Kida, A.; Takashi Kameya, T. A preliminary categorization of end-of-life electrical and electronic equipment as secondary metal resources. Waste Manag. 2011, 31, 2150-2160. [CrossRef] [PubMed]

49. Puttlitz, K.J.; Stalter, K.A. Handbook of Lead-Free Solder Technology for Microelectronic Assemblies; CRC Press: Marcel Dekker, NY, USA, 2004.

50. Syed, S. Recovery of Gold from Secondary Sources-A Review. Hydrometallurgy 2012, 115-116, 30-51. [CrossRef]

51. Vats, M.C.; Singh, S.K.; Vats, M.C.; Singh, S.K. Assessment of Gold and Silver in Assorted Mobile Phone Printed Circuit Boards (PCBs): Original Article. Waste Manag. 2015, 45, 280-288. [CrossRef] [PubMed]

52. Camelino, S.; Rao, J.; Padilla, R.L.; Lucci, R. Initial Studies about Gold Leaching from Printed Circuit Boards (PCB's) of Waste Cell Phones. Procedia Mater. Sci. 2015, 9, 105-112. [CrossRef]

53. Namias, J. The Future of Electronic Waste Recycling in the United States: Obstacles and Domestic Solutions; Columbia University: New York, NY, USA, 2013; Available online: http://www.seas.columbia.edu/earth/ wtert/sofos/Namias_Thesis_07-08-13.pdf (accessed on 10 December 2019).

54. Hadi, P.; Xu, M.; Lin, C.S.K.; Hui, C.-W.; McKay, G. Waste printed circuit board recycling techniques and product utilization. J. Hazard. Mater. 2015, 283, 234-243. [CrossRef]

55. D'Adamo, I.; Ferella, F.; Gastaldi, M.; Maggiore, F.; Rosa, P.; Terzi, S. Towards sustainable recycling processes: Wasted printed circuit boards as a source of economic opportunities. Resour. Conserv. Recycl. 2019, 149, 455-467. [CrossRef]

56. Ferella, F.; de Michelis, I.; Scocchera, A.; Pelino, M.; Vegliò, F. Extraction of metals from automotive shredder residue: Preliminary results of different leaching systems. Chin. J. Chem. Eng. 2015, 23, 417-424. [CrossRef]

57. Cui, J.; Forssberg, E. Mechanical Recycling of Waste Electric and Electronic Equipment: A Review. J. Hazard. Mater. 2003, 99, 243-263. [CrossRef]

58. Gungor, A.; Gupta, S.M. Disassembly Sequence Planning for Products with Defective Parts in Product Recovery. Comput. Ind. Eng. 1998, 35, 161-164. [CrossRef]

59. Rousis, K.; Moustakas, K.; Stylianou, M.; Papadopoulos, A.; Loizidou, M. Management of Waste from Electrical and Electronic Equipment: The Case of Television Sets and Refrigerators. J. Environ. Eng. Sci. 2008, 7, 105-114. [CrossRef]

60. Gupta, S.M.; McLean, C.R. Disassembly of Products. Comput. Ind. Eng. 1996, 31, 225-228. [CrossRef]

61. Gungor, A.; Gupta, S.M. Issues in Environmentally Conscious Manufacturing and Product Recovery: A Survey. Comput. Ind. Eng. 1999, 36, 811-853. [CrossRef]

62. Kuo, T.C. Disassembly Sequence and Cost Analysis for Electromechanical Products. Robot. Comput. Integr. Manuf. 2000, 16, 43-54. [CrossRef]

63. Feldmann, K.; Trautner, S.; Meedt, O. Innovative Disassembly Strategies Based on Flexible Partial Destructive Tools. Annu. Rev. Control 1999, 23, 159-164. [CrossRef]

64. Scholz-Reiter, B.; Scharke, H.; Hucht, A. Flexible Robot-Based Disassembly Cell for Obsolete TV-Sets and Monitors. Robot. Comput. Integr. Manuf. 1999, 15, 247-255. [CrossRef]

65. Moroni, M.; Lupo, E.; Pelle, V.; Pomponi, A.; Marca, F. Experimental Investigation of the Productivity of a Wet Separation Process of Traditional and Bio-Plastics. Separations 2018, 5, 26. [CrossRef]

66. Marca, F.L.; Moroni, M.; Cherubini, L.; Lupo, E.; Cenedese, A. Separation of Plastic Waste via the Hydraulic Separator Multidune under Different Geometric Configurations. Waste Manag. 2012, 32, 1306-1315. [CrossRef]

67. Hopewell, J.; Dvorak, R.; Kosior, E. Plastics Recycling: Challenges and Opportunities. Philos. Trans. R. Soc. B Biol. Sci. 2009, 364, 2115-2126. [CrossRef]

68. Al-Salem, S.M.; Lettieri, P.; Baeyens, J. The Valorization of Plastic Solid Waste (PSW) by Primary to Quaternary Routes: From Re-Use to Energy and Chemicals. Prog. Energy Combust. Sci. 2010, 36, 103-129. [CrossRef]

69. Meng, L.; Wang, Z.; Zhong, Y.W.; Guo, L.; Gao, J.T.; Chen, K.Y.; Cheng, H.J.; Guo, Z.C. Supergravity separation for recovering metals from waste printed circuit boards. Chem. Eng. J. 2017, 326, 540-550. [CrossRef]

70. Meng, L.; Guo, L.; Guo, Z. Separation of metals from metal-rich particles of crushed waste printed circuit boards by low-pressure filtration. Waste Manag. 2019, 84, 227-234. [CrossRef] [PubMed] 
71. Silveira, A.V.M.; Cella, M.; Tanabe, E.H.; Bertuol, D.A. Application of Tribo-Electrostatic Separation in the Recycling of Plastic Wastes. Process Saf. Environ. Prot. 2018, 114, 219-228. [CrossRef]

72. Lee, J.-K.; Shin, J.-H. Triboelectrostatic Separation of Pvc Materials from Mixed Plastics for Waste Plastic Recycling. Korean J. Chem. Eng. 2002, 19, 267-272. [CrossRef]

73. Tilmatine, A.; Medles, K.; Younes, M.; Bendaoud, A.; Dascalescu, L. Roll-Type Versus Free-Fall Electrostatic Separation of Tribocharged Plastic Particles. IEEE Trans. Ind. Appl. 2010, 46, 1564-1569. [CrossRef]

74. Wu, G.; Li, J.; Xu, Z. Triboelectrostatic Separation for Granular Plastic Waste Recycling: A Review. Waste Manag. 2013, 33, 585-597. [CrossRef]

75. Jiang, W.; Jia, L.; Zhen-ming, X. A New Two-Roll Electrostatic Separator for Recycling of Metals and Nonmetals from Waste Printed Circuit Board. J. Hazard. Mater. 2009, 161, 257-262. [CrossRef]

76. Hubau, A.; Chagnes, A.; Minier, M.; Touzé, S.; Chapron, S.; Guezennec, A.-G. Recycling-oriented methodology to sample and characterize the metal composition of waste Printed Circuit Boards. Waste Manag. 2019, 91, 62-71. [CrossRef]

77. Ruan, J.; Qin, B.; Huang, J. Controlling measures of micro-plastic and nano pollutants: A short review of disposing waste toners. Environ. Int. 2018, 118, 92-96. [CrossRef]

78. Moyo, T.; Chirume, B.H.; Petersen, J. Assessing alternative pre-treatment methods to promote metal recovery in the leaching of printed circuit boards. Resour. Conserv. Recycl. 2020, 152, 104545. [CrossRef]

79. Hagelüken, C. Metals Recovery from E-Scrap in a Global Environment Technical Capabilities, Challenges \& Experience Gained. In Proceedings of the 6th session of OEWG Basel Convention, Basel, Geneva, 7 Setember 2007; Volume 7.

80. Chancerel, P.; Meskers, C.E.M.; Hagelüken, C.; Rotter, V.S. Assessment of Precious Metal Flows during Preprocessing of Waste Electrical and Electronic Equipment. J. Ind. Ecol. 2009, 13, 791-810. [CrossRef]

81. Gu, F.; Summers, P.A.; Hall, P. Recovering materials from waste mobile phones: Recent technological developments. J. Clean. Prod. 2019, 238, 117657. [CrossRef]

82. Moltó, J.; Font, R.; Gálvez, A.; Conesa, J.A. Pyrolysis and Combustion of Electronic Wastes. J. Anal. Appl. Pyrolysis 2009, 84, 68-78. [CrossRef]

83. Sethurajan, M.; van Hullebusch, E.D.; Fontana, D.; Akcil, A.; Deveci, H.; Batinic, B.; Leal, J.P.; Gasche, T.A.; Kucuker, M.A.; Kuchta, K.; et al. Recent advances on hydrometallurgical recovery of critical and precious elements from end of life electronic wastes-A review. Crit. Rev. Environ Sci. Techno. 2019, 49, 212-275. [CrossRef]

84. Zhu, X.N.; Nie, C.C.; Wang, S.S.; Xie, Y.; Zhang, H.; Lyu, X.J.; Qiu, J.; Li, L. Cleaner approach to the recycling of metals in waste printed circuit boards by magnetic and gravity separation. J. Clean. Prod. 2019. [CrossRef]

85. Ladou, J.; Lovegrove, S. Export of Electronics Equipment Waste. Int. J. Occup. Environ. Health 2008, 14, 1-10. [CrossRef]

86. Mohabuth, N.; Hall, P.; Miles, N. Investigating the Use of Vertical Vibration to Recover Metal from Electrical and Electronic Waste. Miner. Eng. 2007, 20, 926-932. [CrossRef]

87. Habib, M.; Miles, N.J.; Hall, P. Recovering Metallic Fractions from Waste Electrical and Electronic Equipment by a Novel Vibration System. Waste Manag. 2013, 33, 722-729. [CrossRef]

88. Settimo, F.; Bevilacqua, P.; Rem, P. Eddy Current Separation of Fine Non-Ferrous Particles from Bulk Streams. Phys. Sep. Sci. Eng. 2004, 13, 15-23. [CrossRef]

89. Schlett, Z.; Claici, F.; Mihalca, I.; Lungu, M. A New Static Separator for Metallic Particles from Metal-Plastic Mixtures, Using Eddy Currents. Miner. Eng. 2002, 15, 111-113. [CrossRef]

90. Schubert, H.G.; Warlitz, G. Sorting Metal/Non-Metal Mixtures Using a Corona Electrostatic Separator. Aufbereit.-Tech. 1994, 35, 449-456.

91. Ruan, J.; Qian, Y.; Xu, Z. Environment-Friendly Technology for Recovering Nonferrous Metals from e-Waste: Eddy Current Separation. Resour. Conserv. Recycl. 2014, 87, 109-116. [CrossRef]

92. Li, J.; Shrivastava, P.; Gao, Z.; Zhang, H.-C. Printed Circuit Board Recycling: A State-of-the-Art Survey. IEEE Trans. Electron. Packag. Manuf. 2004, 27, 33-42.

93. Guo, J.; Cao, B.; Guo, J.; Xu, Z. A Plate Produced by Nonmetallic Materials of Pulverized Waste Printed Circuit Boards. Environ. Sci. Technol. 2008, 42, 5267-5271. [CrossRef]

94. Kellner, R. Integrated Approach to E-Waste Recycling. In Electronic Waste Management; The Royal Society of Chemistry: London, UK, 2009; pp. 111-160. [CrossRef] 
95. Hamerski, F.; Krummenauer, A.; Bernardes, A.M.; Veit, H.M. Improved settings of a corona-electrostatic separator for copper concentration from waste printed circuit boards. J. Environ. Chem. Eng. 2019, 7, 102896. [CrossRef]

96. Liu, W.; Liang, C.; Qin, W.Q.; Jiao, F. A New Technology for Recovery of Metals from Waste Printed Circuit Boards. Appl. Mech. Mater. 2014, 675-677, 698-703. [CrossRef]

97. Li, J.; Lu, H.; Guo, J.; Xu, Z.; Zhou, Y. Recycle Technology for Recovering Resources and Products from Waste Printed Circuit Boards. Environ. Sci. Technol. 2007, 41, 1995-2000. [CrossRef]

98. Veit, H.M.; Diehl, T.R.; Salami, A.P.; Rodrigues, J.S.; Bernardes, A.M.; Tenório, J.A.S. Utilization of Magnetic and Electrostatic Separation in the Recycling of Printed Circuit Boards Scrap. Waste Manag. 2005, 25, 67-74. [CrossRef]

99. Aman, F.; Morar, R.; Kohnlechner, R.; Samuila, A.; Dascalescu, L. High-Voltage Electrode Position: A Key Factor of Electrostatic Separation Efficiency; IEEE Transactions on Industry Applications: New Jersey, NJ, USA, 2004; Volume 40. [CrossRef]

100. Samuila, A.; Urs, A.; Iuga, A.; Morar, R.; Aman, F.; Dascalescu, L. Optimization of Corona Electrode Position in Roll-Type Electrostatic Separators. IEEE Trans. Ind. Appl. 2005, 41, 527-534. [CrossRef]

101. Lu, H.; Li, J.; Guo, J.; Xu, Z.M. Pulverization Characteristics and Pulverizing of Waste Printed Circuit Boards (Printed Wiring Boards) Based on Resource Utilization. J. Shanghai Jiaotong Univ. 2007, 4, 551-556.

102. Dascalescu, L.; Samuila, A.; Mihalcioiu, A.; Bente, S.; Tilmatine, A. Robust Design of Electrostatic Separation Processes. IEEE Trans. Ind. Appl. 2005, 41,715-720. [CrossRef]

103. Medles, K.; Tilmatine, A.; Miloua, F.; Bendaoud, A.; Younes, M.; Rahli, M.; Dascalescu, L. Set Point Identification and Robustness Testing of Electrostatic Separation Processes. IEEE Trans. Ind. Appl. 2007, 43, 618-626. [CrossRef]

104. Higashiyama, Y.; Asano, K. Recent Progress in Electrostatic Separation Technology. Part. Sci. Technol. 1998, 16, 77-90. [CrossRef]

105. Kiewiet, C.W.; Bergougnou, M.A.; Brown, J.D.; Inculet, I.I. Electrostatic Separation of Fine Particles in Vibrated Fluidized Beds. IEEE Trans. Ind. Appl. 1978, IA-14, 526-530. [CrossRef]

106. Iuga, A.; Samuila, A.; Morar, R.; Bilici, M.; Dascalescu, L. Tribocharging Techniques for the Electrostatic Separation of Granular Plastics from Waste Electric and Electronic Equipment. J. Part. Sci. Technol. 2015, 34, 45-54. [CrossRef]

107. Benabboun, A.; Tilmatine, A.; Brahami, Y.; Bendimerad, S.E.; Miloudi, M.; Medles, K. Experimental Investigation of Electrostatic Separators of Plastic Particles Using Different Charging Devices. Sep. Sci. Technol. 2014, 49, 464-468. [CrossRef]

108. Sohaili, J.; Muniyandi, S.K.; Mohamad, S.S. A Review on Printed Circuit Board Recycling Technology. Int. J. Sci. Eng. Res. 2012, 3, 12-18.

109. Iuga, A.; Samuila, A.; Neamtu, V.; Morar, R.; Beleca, R.; Das, S.; Dascalescu, L. Removal of Metallic Particles from Acrylonitrile Butadiene Styrene Wastes Using Electrostatic Separation Methods. IEEE Trans. Ind. Appl. 2011, 47, 322-330. [CrossRef]

110. Bendaoud, A.; Tilmatine, A.; Medles, K.; Rahli, M.; Huzau, M.; Dascalescu, L. Characterisation of Dual Corona-Electrodes for Electrostatic Processes Applications. In Proceedings of the Conference Record of the 2004 IEEE Industry Applications Conference, 39th IAS Annual Meeting, Seattle, WA, USA, 3-7 October 2004; Volume 3, pp. 1552-1558. [CrossRef]

111. Iuga, A.; Calin, L.; Neamtu, V.; Mihalcioiu, A.; Dascalescu, L. Tribocharging of Plastics Granulates in a Fluidized Bed Device. J. Electrostat. 2005, 63, 937-942. [CrossRef]

112. Park, C.H.; Park, J.K.; Jeon, H.S.; Chun, B.C. Triboelectric Series and Charging Properties of Plastics Using the Designed Vertical-Reciprocation Charger. J. Electrostat. 2008, 66, 578-583. [CrossRef]

113. Al-Salem, S.M.; Lettieri, P.; Baeyens, J. Recycling and Recovery Routes of Plastic Solid Waste (PSW): A Review. Waste Manag. 2009, 29, 2625-2643. [CrossRef] [PubMed]

114. Li, L.; Liu, G.; Pan, D.; Wang, W.; Wu, Y.; Zuo, T. Overview of the Recycling Technology for Copper-Containing Cables. Resour. Conserv. Recycl. 2017, 126, 132-140. [CrossRef]

115. Veit, H.M.; Bernardes, A.M.; Ferreira, J.Z.; Tenório, J.A.S.; Malfatti, C. de F. Recovery of Copper from Printed Circuit Boards Scraps by Mechanical Processing and Electrometallurgy. J. Hazard. Mater. 2006, 137, 1704-1709. [CrossRef] [PubMed] 
116. Jeon, H.S.; Park, C.H.; Cho, B.G.; Park, J.K. Separation of PVC and Rubber from Covering Plastics in Communication Cable Scrap by Tribo-Charging. J. Sep. Sci. Technol. 2009, 44. [CrossRef]

117. Li, J.; Wu, G.; Xu, Z. Tribo-Charging Properties of Waste Plastic Granules in Process of Tribo-Electrostatic Separation. Waste Manag. 2015, 35, 36-41. [CrossRef]

118. Miloudi, M.; Dascalescu, L.; Li, J.; Medles, K.; Tilmatine, A. Improved Overall Performances of a Tribo-Aero-Electrostatic Separator for Granular Plastics from Waste Electric and Electronic Equipment. IEEE Trans. Ind. Appl. 2015, 51, 4159-4165. [CrossRef]

119. Aksa, W.; Medles, K.; Rezoug, M.; Boukhoulda, M.F.; Bilici, M.; Dascalescu, L. Two Stage Electrostatic Separator for the Recycling of Plastics from Waste Electrical and Electronic Equipment. J. Electrostat. 2013, 71, 681-688. [CrossRef]

120. Dascalescu, L.; Zeghloul, T.; Iuga, A. Chapter 4-Electrostatic Separation of Metals and Plastics from Waste Electrical and Electronic Equipment. In WEEE Recycling; Chagnes, A., Cote, G., Ekberg, C., Nilsson, M., Retegan, T., Eds.; Elsevier: Amsterdam, Netherlands, 2016; pp. 75-106. [CrossRef]

121. Zelmat, M.E.; Tilmatine, A.; Touhami, S.; Bendaoud, A.; Medles, K.; Ouiddir, R.; Dascalescu, L. Experimental Investigation of a New Tribo-Aeroelectrostatic Separation Process for Micronized Plastics from WEEE. IEEE Trans. Ind. Appl. 2017, 53, 4950-4956. [CrossRef]

122. Cangialosi, F.; Crapulli, F.; Intini, G.; Liberti, L.; Notarnicola, M. Modelling of Tribo-Electrostatic Separation for Industrial by-Products Recycling. WIT Trans. Ecol. Environ. 2006, 92, 101-110. [CrossRef]

123. Zhang, C. Completely Bounded Banach-Mazur Distance. Proc. Edinburgh Math. Soc. 1997, 40, $247-260$. [CrossRef]

124. He, J.; Duan, C. Recovery of metallic concentrations from waste printed circuit boards via reverse floatation. Waste Manag. 2017, 60, 618-628. [CrossRef] [PubMed]

125. Freitas, M.B.J.G.; Celante, V.G.; Pietre, M.K. Electrochemical Recovery of Cobalt and Copper from Spent Li-Ion Batteries as Multilayer Deposits. J. Power Sources 2010, 195, 3309-3315. [CrossRef]

126. Sepúlveda, A.; Schluep, M.; Renaud, F.G.; Streicher, M.; Kuehr, R.; Hagelüken, C.; Gerecke, A.C. A Review of the Environmental Fate and Effects of Hazardous Substances Released from Electrical and Electronic Equipments during Recycling: Examples from China and India. Environ. Impact Assess. Rev. 2010, 30, $28-41$. [CrossRef]

127. Lee, J.; Pandey, B.D. Bio-Processing of Solid Wastes and Secondary Resources for Metal Extraction-A Review. Waste Manag. 2012, 32, 3-18. [CrossRef] [PubMed]

128. Zhou, Y.; Qiu, K. A New Technology for Recycling Materials from Waste Printed Circuit Boards. J. Hazard. Mater. 2010, 175, 823-828. [CrossRef]

129. Traversi, R.; Becagli, S.; Calzolai, G.; Chiari, M.; Giannoni, M.; Lucarelli, F.; Nava, S.; Rugi, F.; Severi, M.; Udisti, R. A Comparison between PIXE and ICP-AES Measurements of Metals in Aerosol Particulate Collected in Urban and Marine Sites in Italy. Nucl. Instrum. Methods Phys. Res. Sect. B Beam Interact. Mater. Atoms 2014, 318, 130-134. [CrossRef]

130. Cucchiella, F.; D'Adamo, I.; Koh, L.; Rosa, P. Recycling of WEEEs: An economic assessment of present and future e-waste streams. Renew. Sustain. Energy Rev. 2015, 51, 263-272. [CrossRef]

131. De Marco, I.; Caballero, B.M.; Chomón, M.J.; Laresgoiti, M.F.; Torres, A.; Fernández, G.; Arnaiz, S. Pyrolysis of Electrical and Electronic Wastes. J. Anal. Appl. Pyrolysis 2008, 82, 179-183. [CrossRef]

132. Yang, H.; Liu, J.; Yang, J. Leaching Copper from Shredded Particles of Waste Printed Circuit Boards. J. Hazard. Mater. 2011, 187, 393-400. [CrossRef]

133. Liang, G.; Tang, J.; Liu, W.; Zhou, Q. Optimizing Mixed Culture of Two Acidophiles to Improve Copper Recovery from Printed Circuit Boards (PCBs). J. Hazard. Mater. 2013, 250-251, 238-245. [CrossRef]

134. Birloaga, I.; De Michelis, I.; Ferella, F.; Buzatu, M.; Vegliò, F. Study on the Influence of Various Factors in the Hydrometallurgical Processing of Waste Printed Circuit Boards for Copper and Gold Recovery. Waste Manag. 2013, 33, 935-941. [CrossRef] [PubMed]

135. Bigum, M.; Brogaard, L.; Christensen, T.H. Metal Recovery from High-Grade WEEE: A Life Cycle Assessment. J. Hazard. Mater. 2012, 207-208, 8-14. [CrossRef] [PubMed]

136. Yeh, C.-H.; Xu, Y. Sustainable Planning of E-Waste Recycling Activities Using Fuzzy Multicriteria Decision Making. J. Clean. Prod. 2013, 52, 194-204. [CrossRef]

137. Ghosh, B.; Ghosh, M.K.; Parhi, P.; Mukherjee, P.S.; Mishra, B.K. Waste Printed Circuit Boards Recycling: An Extensive Assessment of Current Status. J. Clean. Prod. 2015, 94, 5-19. [CrossRef] 
138. Fogarasi, S.; Imre-Lucaci, F.; Ilea, P.; Imre-Lucaci, Á. The Environmental Assessment of Two New Copper Recovery Processes from Waste Printed Circuit Boards. J. Clean. Prod. 2013, 54, 264-269. [CrossRef]

139. Lister, T.E.; Wang, P.; Anderko, A. Recovery of Critical and Value Metals from Mobile Electronics Enabled by Electrochemical Processing. Hydrometallurgy 2014, 149, 228-237. [CrossRef]

140. Kim, E.; Kim, M.; Lee, J.; Jeong, J.; Pandey, B.D. Leaching Kinetics of Copper from Waste Printed Circuit Boards by Electro-Generated Chlorine in $\mathrm{HCl}$ Solution. Hydrometallurgy 2011, 107, 124-132. [CrossRef]

141. Casas, J.M.; Acuña-Goycolea, P.; Crisóstomo, G.; Cifuentes, L. Processing of a Ferric Anolyte Produced by a Copper Electrowinning Cell Based on Reactive Electro Dialysis. Miner. Eng. 2008, 21, 525-532. [CrossRef]

142. Fogarasi, S.; Imre-Lucaci, F.; Imre-Lucaci, Á.; Ilea, P. Copper Recovery and Gold Enrichment from Waste Printed Circuit Boards by Mediated Electrochemical Oxidation. J. Hazard. Mater. 2014, 273, $215-221$. [CrossRef]

143. Diaz, L.A.; Lister, T.E.; Parkman, J.A.; Clark, G.G. Comprehensive Process for the Recovery of Value and Critical Materials from Electronic Waste. J. Clean. Prod. 2016, 125, 236-244. [CrossRef]

144. Imre-Lucaci, F.; Fogarasi, S.; Ilea, P.; Tamasan, M. Copper Recovery from Real Samples of WPCBs by Anodic Dissolution. Environ. Eng. Manag. J. 2012, 11, 1439-1444. [CrossRef]

145. Ping, Z.; ZeYun, F.; Jie, L.; Qiang, L.; Guang Ren, Q.; Ming, Z. Enhancement of Leaching Copper by Electro-Oxidation from Metal Powders of Waste Printed Circuit Board. J. Hazard. Mater. 2009, 166, 746-750. [CrossRef] [PubMed]

146. Imre-Lucaci, Á.; Nagy, M.; Imre-Lucaci, F.; Fogarasi, S. Technical and environmental assessment of gold recovery from secondary streams obtained in the processing of waste printed circuit boards. Chem. Eng. J. 2017, 309, 655-662. [CrossRef]

147. Kumari, A.; Jha, M.K.; Lee, J.; Singh, R.P. Clean Process for Recovery of Metals and Recycling of Acid from the Leach Liquor of PCBs. J. Clean. Prod. 2016, 112, 4826-4834. [CrossRef]

148. Lei, J.; Yuan, G.; Weerachanchai, P.; Lee, S.W.; Li, K.; Wang, J.Y.; Yang, Y. Investigation on Thermal Dechlorination and Catalytic Pyrolysis in a Continuous Process for Liquid Fuel Recovery from Mixed Plastic Wastes. J. Mater. Cycles Waste Manag. 2018, 20, 137-146. [CrossRef]

149. Zabłocka-Malicka, M.; Szczepaniak, W.; Rutkowski, P.; Ochromowicz, K.; Leśniewicz, A.; Chęcmanowski, J. Decomposition of the ISA-Card under Steam for Valorized Polymetallic Raw Material. J. Anal. Appl. Pyrolysis 2018, 130, 256-268. [CrossRef]

150. Zhao, X.; Jiang, G.; Li, A.; Wang, L. Economic Analysis of Waste-to-Energy Industry in China. Waste Manag. 2016, 48, 604-618. [CrossRef]

151. Othman, N.; Mohd Sidek, L.; Ahmad Basri, E.N.; Muhd Yunus, M. Electronic Plastic Waste Management in Malaysia: The Potential of Waste to Energy Conversion. In Proceedings of the 2009 3rd International Conference on Energy and Environment (ICEE), Malacca, Malaysia, 7-8 December 2009. [CrossRef]

152. Jayaraman, K.; Vejayon, S.; Raman, S.; Mostafiz, I. The proposed e-waste management model from the conviction of individual laptop disposal practices-An empirical study in Malaysia. J. Clean. Prod. 2019, 208, 688-696. [CrossRef]

153. Szałatkiewicz, J. Energy Recovery from Waste of Printed Circuit Boards in Plasmatron Plasma Reactor. Pol. J. Environ. Stud. 2014, 23, 277-281.

154. Altarawneh, M.; Ahmed, O.H.; Jiang, Z.T.; Dlugogorski, B.Z. Thermal Recycling of Brominated Flame Retardants with $\mathrm{Fe}_{2} \mathrm{O}_{3}$. J. Phys. Chem. A 2016, 120, 6039-6047. [CrossRef]

155. Imai, T.; Hamm, S.; Rothenbacher, K.P. Comparison of the Recyclability of Flame-Retarded Plastics. Environ. Sci. Technol. 2003, 37, 652-656. [CrossRef] [PubMed]

156. Kasper, A.C.; Gabriel, A.P.; de Oliveira, E.L.B.; de Freitas Juchneski, N.C.; Veit, H.M. Electronic Waste Recycling BT-Electronic Waste: Recycling Techniques; Veit, H.M., Moura Bernardes, A., Eds.; Springer International Publishing: Cham, Switzerland, 2015; pp. 87-127. [CrossRef]

157. Long, L.; Sun, S.; Zhong, S.; Dai, W.; Liu, J.; Song, W. Using Vacuum Pyrolysis and Mechanical Processing for Recycling Waste Printed Circuit Boards. J. Hazard. Mater. 2010, 177, 626-632. [CrossRef] [PubMed]

158. Evangelopoulos, P.; Kantarelis, E.; Yang, W. Investigation of the Thermal Decomposition of Printed Circuit Boards (PCBs) via Thermogravimetric Analysis (TGA) and Analytical Pyrolysis (Py-GC/MS). J. Anal. Appl. Pyrolysis 2015, 115, 337-343. [CrossRef]

159. Xiang, D.; Mou, P.; Wang, J.; Duan, G.; Zhang, H.C. Printed Circuit Board Recycling Process and Its Environmental Impact Assessment. Int. J. Adv. Manuf. Technol. 2007, 34, 1030-1036. [CrossRef] 
160. Havlik, T.; Orac, D.; Petranikova, M.; Miskufova, A. Hydrometallurgical Treatment of Used Printed Circuit Boards after Thermal Treatment. Waste Manag. 2011, 31, 1542-1546. [CrossRef]

161. Fujita, T.; Ono, H.; Dodbiba, G.; Yamaguchi, K. Evaluation of a Recycling Process for Printed Circuit Board by Physical Separation and Heat Treatment. Waste Manag. 2014, 34, 1264-1273. [CrossRef]

162. Tuncuk, A.; Stazi, V.; Akcil, A.; Yazici, E.Y.; Deveci, H. Aqueous Metal Recovery Techniques from E-Scrap: Hydrometallurgy in Recycling. Miner. Eng. 2012, 25, 28-37. [CrossRef]

163. Moberg, Å.; Johansson, M.; Finnveden, G.; Jonsson, A. Printed and Tablet E-Paper Newspaper from an Environmental Perspective-A Screening Life Cycle Assessment. Environ. Impact Assess. Rev. 2010, 30, 177-191. [CrossRef]

(C) 2019 by the authors. Licensee MDPI, Basel, Switzerland. This article is an open access article distributed under the terms and conditions of the Creative Commons Attribution (CC BY) license (http://creativecommons.org/licenses/by/4.0/). 